\title{
Galego e português no Cancioneiro inédito de Cipriano Torre Enciso
}

\section{Galician language and Portuguese language in the unpublished Cancioneiro by Cipriano Torre Enciso}

\author{
Xosé Manuel Sánchez Rei \\ Universidade da Coruña - Grupo ILLA (España) \\ sanrei@udc.gal
}

Recibido o 07/06/2019

Aceptado o 01/02/2020

\section{Resumo}

Os materiais de literatura oral coligidos pelo polígrafo galego Cipriano Torre Enciso (1902-1994) enformam uma obra de aproximadamente 7.000 textos de extração popular. Entre as caraterísticas que a definem, verifica-se uma de relevância no conjunto de trabalhos editoriais galegos desta natureza, como é o facto de o coletor incorporar textos provenientes do cancioneiro português. Esse traço pode comprovar-se do ponto de vista linguístico ao se detetarem fenómenos gramaticais e lexicais presentemente mais próprios ou exclusivos da língua em Portugal do que na Galiza.

\section{Palabras-clave}

Cancioneiro tradicional; galego; gramática e léxico; português.

\section{Sumario}

1. Introdução. 2. Traços gerais do CTE. 2.1. A cifra de quadras. 2.2. A organizaçáo: pastas, temas e fichas. 2.3. As fontes. 2.3.1. Literatura tradicional publicada na Galiza. 2.3.2. Literatura culta. 2.3.3. A presumível compilaçáo direta. 2.3.4. A colaboraçáo de terceiras pessoas. 2.3.5. A literatura tradicional portuguesa. 2.4. O âmbito territorial. 2.5. A intervençáo do editor. 3. Galego e português no CTE. 3.1. A língua dos cancioneiros, uma variedade popular. 3.2. Consideraçôes gerais. 3.3. Alguns aspetos gramaticais. 3.3.1. Sufixos e terminaçóes. 3.3.2. Particularidades dos verbos irregulares. 3.3.3. O uso dos tempos compostos. 3.3.4. Os pronomes pessoais. 3.4. Algumas questões lexicais. 4. Conclusóes.

\begin{abstract}
The materials of oral literature gathered by the Galician polygraph Cipriano Torre Enciso (1902-1994) constitute a work of approximately 7,000 texts of popular origin. Among the characteristics that define it, there is one feature of relevance within the set of $\mathrm{Ga}$ lician works of this nature: the fact that he incorporated texts from the Portuguese folksong repertoire. This feature can be verified from the linguistic point of view when detecting grammatical and lexical phenomena currently more characteristic or exclusive of Portugal than of Galicia.
\end{abstract}

\section{Keywords}

Traditional songbook; Galician language; grammar and lexis; Portuguese language.

\section{Contents}

1. Introduction. 2. General characteristics of the CTE. 2.1. Number of poems. 2.2. Organisation: folders, topics and index cards. 2.3. Sources. 2.3.1. Traditional literature published in Galicia. 2.3.2. Cultured literature. 2.3.3. The alleged direct compilation. 2.3.4. The collaboration of third parties. 2.3.5. Portuguese traditional literature. 2.4. The territorial scope. 2.5. The editor's intervention. 3. Galician and Portuguese in CTE. 3.1. The language of the songbooks, a popular variety. 3.2. General remarks. 3.3. Some grammatical aspects. 3.3.1. Suffixes and terminations. 3.3.2. Particularities of irregular verbs. 3.3.3. Use of compound verbal tenses. 3.3.4. Personal pronouns. 3.4. Some lexical questions. 4. Conclusions. 


\section{Introdução}

Cipriano Torre Enciso (Corunha, 1902 - Madrid, 1994), advogado, jornalista, membro correspondente da Real Academia Galega, fundador de Radio Nacional de España, estudioso da cultura galega e autor (ou co-autor) de vários livros de diversa temática ${ }^{1}$, também se dedicou, enquanto amador, à compilação de literatura tradicional, nomeadamente textos poéticos e, em menor medida, textos paremiológicos. Não se sabe com total certeza quando é que começou este trabalho, mas, do que pudemos deduzir das conversas com a sua família, e em especial com a professora da Universidade de Lamar (USA), Dra. Catalina T. Castillón, nas décadas de 60 e 70 do passado século levou a cabo a maior parte dessas tarefas como coletor. Isto situa-o, de acordo com a periodização indicada por Blanco Pérez (1994: 162-179), na quarta das etapas de compilaçáo de literatura oral galega, que principia depois da Guerra Civil Espanhola (1936-1939) e que chega até aos nossos días; este quarto período carateriza-se por corresponder a um tempo de incertezas para a sobrevivência da poesia e canto tradicionais, derivadas, as mais delas, das profundas transformaçóes sociais acontecidas na segunda metade do século $\mathrm{xx}^{2}$.

Das mesmas informaçôes familiares conhecemos, por sua vez, que nos primórdios dos anos 80 já se achava coligida a prática totalidade dos materiais que constituem o que se pode denominar Cancioneiro de Torre Enciso (doravante CTE). Estamos, pois, perante um trabalho inédito acerca do qual não há qualquer referência em

1. Cfr., entre outros, La marcha sobre Barcelona (1939, escrito em parceria com D. Muro Zegri); Los mejores cuentos infantiles. 10 obras maestras de la literatura española (1941, adaptados por Torre Enciso); Juguetes. Poemas para niños y mayores (1942, com J. Soler Serrano); La vuelta al deporte en 80 relatos de humor (1943); Los mejores cuentos infantiles. 10 obras maestras de la literatura francesa (1954, adaptados por Torre Enciso); Panxoliñas. Retabro galego de Nadal (1956); Camelias brancas. Nosa Señora en Galicia (1958); Cocina gallega enxebre. Asi se come en Galicia (1982); Pescados y mariscos (1982); etc.

2. Repare-se nas próprias palavras de Blanco Pérez (1994: 164, 178-179), autor que assinala, como uns dos principais motivos da crise da literatura anónima, as grandes mudanças acontecidas na sociedade galega a partir da década de 50 do século xx, entre as quais pondera uma brutal desruralização: "Os cambios producidos nos modos de vida tradicionais afectaron, pois, notablemente á literatura popular galega, que se viu substituída nas funcións de divertir, entreter, galantear, acompańar o traballo, compensar as limitacións da realidade, etc. pola canción comercial en castelán, de acceso moi doado; e noutras funcións como ensinar e cohesionar, polos libros da escola e a información da radio e da prensa [...]. O asentamento masivo da poboación rural no medio urbano trouxo consigo un cambio xeneralizado nos seus costumes e formas de vida (que mantivera durante séculos), e na súa adaptación houbo de renunciar a unha boa parte do seu patrimonio cultural anterior, que xa non tińa valor funcional no novo hábitat; entre ese patrimonio esquencido ou desactivado está a literatura tradicional en galego". Náo podemos deixar de mencionar aqui a figura de Ramón Otero Pedrayo (1888-1976), um dos vultos da cultura galega contemporânea, que foi testemunha da evoluçáo decadente do mundo rural e que também a soube deslocar com brilhantismo à expressão literária. 
estudos especializados contemporâneos, pelo menos naqueles que foram utilizados para este contributo ${ }^{3}$. No momento de redigirmos as presentes páginas, os originais do CTE acham-se custodiados pela Dra. Catalina T. Castillón, a quem agradecemos imenso a cedência de uma cópia para a elaboração deste contributó ${ }^{4}$.

É a nossa intenção darmos conta das caraterísticas do CTE, especialmente de uma, como é o facto de o compilador incorporar textos da literatura tradicional portuguesa, o que é certamente inovador no panorama dos trabalhos desta natureza. Para tudo isto, em primeiro lugar, desenvolveremos uma exposição geral dos elementos que definem o CTE, em que poderemos ver que alguns são comuns a outras coleçóes de literatura oral, enquanto outros patenteiam-se idiossincráticos da obra. E, em segundo lugar, trataremos de verificar a proveniência lusitana de um notável número de cantares, assunto para o qual nos basearemos no tipo de linguagem atestada.

\section{Traços gerais do CTE}

Todos os cancioneiros que compóem o repertório da lírica tradicional galega apresentam uma série de caraterísticas que serve para os singularizar relativamente a outras coleçôes: âmbito territorial, número de textos, temática, etc. A compilação de Cipriano Torre Enciso não constitui uma exceção a esse respeito e, desta maneira, existem vários elementos que lhe conferem uma clara particularizaçáo.

\subsection{A cifra de quadras}

O primeiro deles assenta no número de amostras: sem termos em conta os textos paremiológicos, representados também no cancioneiro embora numas proporçôes menores (os quais foram devidamente expurgados do nosso cômputo), cantares de diversas temáticas e procedências geográficas e também datáveis em diferentes épocas ${ }^{5}$

3. Vejam-se, a este propósito, os trabalhos de Blanco Pérez (1994, 1996 e 1997) ou Sánchez Rei (2006).

4. Com posterioridade às primeiras versóes deste estudo, a edição foi dada a lume por Sánchez Rei \& Castillón (2019).

5. Repare-se em que por simples acumulação do corpus que se pôde conservar, existem diferentes degraus de localização cronológica para as quadras do cancioneiro em geral e no de Torre Enciso em particular. Cabanillas (1976: 16), neste sentido, afirma que a origem do tal corpus é capaz de remontar quando menos três séculos, pois, na sua opiniáo, as "coplas que hoxe escoitamos con ledicia arrincan en boa contía, sen dúbida, ao menos no que toca a verbas e feituras, dos tres séculos derradeiros". Inclusivamente, ter-se-ia de formular a pergunta de se, na realidade, não se poderia pensar em épocas anteriores para a génese desta literatura, vendo o que parece ter sucedido com outras tradiçôes literárias de transmissão anónima linguística e geograficamente próximas, como a castelhana, a judeu-espanho- 
enformam uma cifra que anda à volta de 7.000 composiçóes. Note-se, a este propósito, que muitos outros famosos cancioneiros galaicos, quer pelas condiçóes em que foram coligidos, quer pelas finalidades que perseguiam, distam bastante desta cifra: a obra de Casto Sampedro (CMG), coligida entre finais do século xIX e os inícios da seguinte centúria, oferece mais um pouco de 700 cantares acompanhados de notação musical; por sua vez, a coleçáo de Juan Antonio Saco Arce (LPG), elaborada na segunda metade do século XIx, deixa um número próximo dos 1.400 textos; o cancioneiro de José Pérez Ballesteros (CPG), publicado nos anos 1885-1886, consegue enformar uma obra de cerca de 2.600 estrofes; o trabalho de Ramón Cabanillas (CPGA), dado a lume pela primeira vez em 1951, quase chega à cifra de 900 textos; a obra de Dorothé Schubarth e Antón Santamarina (CPGAL), a mais completa feita até ao momento, classifica mais de 5.000 mostras com as correspondentes partituras; etc.

Perante este estado de coisas, o CTE torna-se, em termos quantitativos, num dos mais importantes do panorama da literatura tradicional galega do século xx. É certo, contudo, que alguns desses textos constituem versóes de outras quadras coligidas no próprio CTE ou até noutros cancioneiros, nas quais aparecem variantes dialetais, gramaticais, lexicais ou textuais, situação que costuma produzir-se neste tipo de manifestação artística. Porém, julgamos que o produto final no seu conjunto se torna uma preciosa ferramenta para as pessoas que se dedicam ao estudo da literatura oral e que, no dia em que for publicada, será sem qualquer dúvida um referente pela quantidade de poesias incluídas e pelo aproveitamento que desses cantares se puider desenvolver em termos culturais, etnológicos, históricos, linguísticos e dialetais, toponomásticos, etc.

\subsection{A organizaçáo: pastas, temas e fichas}

O CTE, externamente, está agrupado em pastas em que se contêm os textos. No geral, em cada uma delas vão aparecendo estrofes de variadas temáticas, incluindo quadras de diversa índole relativamente aos assuntos de que tratam os cantares tradicionais (agravos, casamentos, doenças, desafios, despedidas, figuras populares do mundo rural, profissóes e ofícios, relaçôes amorosas, religiosidade e superstiçóes, saudades, morte, etc.). Há pastas, contudo, que recolhem praticamente poesias de uma única tipología, como a número $\mathrm{X}$, dedicada a cantares de tema filosófico ou reflexivo (exceto nuns poucos casos), ou o número XII, consagrada quase exclusivamente a estrofes amorosas. Quanto à apresentação formal externa, algumas pastas dispóem de uma sorte de capa numerada (VIII, IX, XI, XVI, etc.), enquanto outras carecem dela (II, IV, XII, etc.).

la, a catalâ, etc. Frenk (2006: 124-145), a este respeito, detetou fragmentos de cantares que, sendo conhecidos na Idade Contemporânea, poderiam ter-se gerado nos séculos XVI ou XVII. 
Dentro de cada pasta, o coletor organizou os cantares por temáticas, acompanhando assim uma prática assaz recorrente nesta tipologia de trabalhos. As epígrafes figuram umas vezes em galego, outras em espanhol. Em concreto, a resumirmos uma possível classifição e unificando os títulos para o galego, os eixos gerais ficam distribuídos ao longo das pastas em "Adiviñas", "Aguinaldos", "Amores", "Cantos e danzas", "Casados e casadas", "Corro", "Diálogos", "Filosofía", "Gastronomía”, "Humorísticos”, "Infantís”, "Maios”, "Morte”, "Nadal”, "Nai / Berce”, "Oficios”, "Reises", "Relixión", "Rondas", "Saudades / Despedidas / Ausencias", "Supersticións e bruxas", "Solteiros e solteiras", "Vilancicos (e panxolińas)", "Xaneiro", "Xeografía e "Xogos". Com todas as matizaçôes necessárias, a tal organização cumpre os parâmetros seguidos em maior ou em menor medida neste tipo de obras, de maneira que os grandes temas recorrentes nos cancioneiros clássicos tradicionais galego-portugueses estão presentes nos materiais do CTE 6 .

Finalmente, o método de trabalho levado a cabo por Torre Enciso para recolher todas essas amostras de literatura oral consistiu em as apontar em folhas de papel-cebola, nas quais, segundo o que observámos, pode haver até um máximo de três estrofes. Por sua vez, em páginas já de papel mais habitual, o número de poesias pode ver-se incrementado notavelmente. Uma vez realizado o trabalho, a maior parte dos cantares foi mecanografada; algumas poesias, as menos numerosas, conservam-se manuscritas (veja-se o Apêndice).

\subsection{As fontes}

Uma leitura do Cancioneiro de Torre Enciso permite comentarmos a procedência dos cantares, em que se podem distinguir várias fontes, segundo se verá na presente secção. Antes de mais, e secundarizando as origens que se verão mais abaixo (i.e., os textos publicados, a compilaçáo direta, a ajuda de diversas pessoas, etc.), devemos assinalar que todos os textos são de literatura tradicional ou popular. Dito com outras palavras, no CTE não se verificam amostras de cantares identificados por serem da elaboraçáo de Torre Enciso ou de outros autores, pois todas as poesias incluídas provêm da tradiçấo anónima.

6. Temos de salientar, porém, que a classificação por temas é uma possibilidade que fica muito subordinada à vontade da pessoa responsável pela edição, pois não existem duas propostas totalmente coincidentes. Neste sentido, a exposição de motivos temáticos costuma fazer parte dos consabidos estudos introdutórios ou textos prefaciais que acompassam os cancioneiros, como o prólogo - dotado de grandes doses de lirismo - feito por Cabanillas (1976), a "Introdução" de Nunes (1975), o texto de Afonso (2005), etc. Produto da imensa quantidade de temas que se podem encontrar dentro da literatura tradicional é o facto de a revista Escrita Contemporánea, dada a lume pela Asociación de Escritoras e Escritores en Lingua Galega (AELG), recolher as atas das Xornadas de Literatura Oral, as quais são dedicadas em cada edição a uma temática recorrente nessa tipologia de textos. 


\subsubsection{Literatura tradicional publicada na Galiza}

Temos de fazer referência em primeiro lugar ao legado tradicional do cancioneiro galego presente em diversas obras, com as quais muito provavelmente interagiria o compilador: estamos a pensar em coleçôes como CPG, CPGA, CPL, etc. Desconhecemos em que medida Torre Enciso copiou ou adaptou estrofes provenientes destes outros trabalhos, mas podemos pensar que talvez de aqui proceda uma interessante parte de textos do CTE a teor de algumas coincidências que pudemos detetar. $\mathrm{Na}$ realidade, trata-se de uma prática náo desconhecida para os folcloristas galegos, pois, não raramente, na sua vontade de compilarem antes do que escolherem, costumavam selecionar ou incluir textos de outras obras similares ${ }^{7}$. Correspondendo, portanto, a um proceder assaz comum, e com todas as cautelas necessárias a esse respeito, quiçá se possa pensar nessas origens para o caso da amostra seguinte, também registada, com pequenas variantes (i.e. á noite $\sim$ de noite, etc.) no cancioneiro de José Pérez Ballesteros (CPG):

\author{
Chamácheme pouca roupa, \\ si a tes, é teu proveito; \\ teño menos que quitar \\ á noite cando me deito. \\ $(\mathrm{CTE}, \mathrm{I})^{8}$
}

\author{
Chamácheme pouca roupa \\ ¡si a tès é teu proveito! \\ ¡teño menos que quitar \\ de noite cando me deito! \\ (CPG II, 170)
}

Sucede qualquer coisa similar com o par de exemplos a seguir relativamente à obra de Ramón Cabanillas, em que se verifica alguma mínima diferença (i.e. naciche - naciches, etc.):

\author{
Á túa porta, meniña, \\ hai dúas horas que chamo; \\ non naciche para amores \\ que tes o sono pesado. \\ (CTE, I)
}

\author{
Á túa porta, meniña, \\ hai duas horas que chamo, \\ non naciches para amores \\ que tes o sono pesado. \\ (CPGA 61)
}

7. José Pérez Ballesteros, por exemplo, vai indicando ao longo das páginas do seu Cancioneiro que determinadas quadras provêm dos trabalhos de Marcial Valladares, Saco Arce, Milà i Fontanals, Manuel Murguía, Eduardo Pondal, Rosalía de Castro, Salvador Golpe, etc. Também Lorenzo Fernández (1973: 7) fez constar que nem todas as poesias do CPL foram "recolleitadas polo autor", pois algumas já tinham sido publicadas por estudiosos como Fernández Alonso, Saco Arce ou Florentino Cuevillas.

8. Referenciamos a localização dos cantares pelo número da pasta em que foram agrupados. No resto de obras (CPG, CPGA, etc.) indicamos o número de página. Do mesmo modo, dado que pudemos verificar a existência de várias soluçóes gráficas às vezes nem sempre congruentes devido ao contexto histórico e às circunstâncias sócio-culturais da época, unificamos a ortografia dos textos para a fazermos coincidir com a variedade padrão atual do galego recolhida em RAG / ILG (2003). 
E também parece constatar-se ao compararmos o CTE com o cancioneiro de Xoaquín Lorenzo Fernández, pelo menos nalgumas quadras como a seguinte:

\author{
Meu Manoel, meu Manoeliño, \\ meu Manoel feito de cera; \\ quen me dera se-lo lume \\ que ó meu Manoel derretera! \\ (CTE, IX)
}

\author{
Meu Manoel, meu Manoeliño \\ Meu Manoel feito de cera: \\ quén me dera selo lume \\ que ó meu Manoel derretera! \\ (CPL 97)
}

\title{
2.3.2. Literatura culta
}

Mais uma fonte onde parece ter-se inspirado para coligir textos vem dada pela literatura de autoria individual, pois alguns desses cantares foram transmitidos e popularizados mercê ao aproveitamento literário que deles fizeram vultos da literatura galega contemporânea. Na realidade, conforme diz Blanco (1992: 77), corresponde a um mecanismo de projeção social e cultural que conta com magníficos exemplos tanto na cultura galega quanto noutros países, como é o caso de Curros Enríquez (1851-1908), de Rosalía de Castro (1837-1885), de Robert Burns (1751-1796), etc. Novamente com toda a dose precisa de prudência, acreditamos em que essa origem poderia explicar a presença das estrofes seguintes no CTE, as quais foram glossadas por Rosalía de Castro em Cantares Gallegos (1863) e conseguiram ser singularmente conhecidas na atualidade:

\author{
Adiós rios, adiós fontes, \\ adiós regatos pequenos; \\ adiós vista dos meus ollos, \\ non sei cando nos veremos! \\ (CTE, XIX) \\ Has de cantar, que che hei de dar zonchos, \\ has de cantar, que che hei de dar moitos; \\ has de cantar e has de cantar, \\ has de cantar, que chos hei de dar. \\ (CTE, VI)
}

Contudo, Torre Enciso cita ocasionalmente a obra ou autor de onde presumivelmente tirou o texto, se bem que não se trata de uma prática muito frequente. Deste modo, numas anotaçóes que adiciona a várias quadras, revela tanto a origem bibliográfica das composiçóes quanto a vigência delas em determinadas zonas: "Este cantar 
figura en el libro del erudito Sr. Tobio Campos, pero en Vivero, donde aquel estuvo de maestro, se cantó mucho".

\subsubsection{A presumível compilação direta}

A oralidade, ora em forma de cantares musicados, ora em forma de poesías recitadas, parece ter sido capaz de proporcionar a Torre Enciso mais um recurso de onde extrair materiais. Das conversas de trabalho que mantivemos com a família do polígrafo, pudemos deduzir que uma parte do corpus do cancioneiro apresenta esta proveniência. Apesar de viver normalmente em Madrid, sempre que Torre Enciso visitava a Galiza ou Portugal, frequentava, se surgia a ocasião, festas, mercados e romagens, onde registava estrofes tradicionais de mulheres e homens que interagiam como informantes: artesãos, gentes do campo, marinheiros, trabalhadoras domésticas, redeiras, vendedeiras, etc. ${ }^{9}$ Isto pode explicar a grande quantidade de variantes com que se documentam os textos, pois a mesma quadra, como ainda hoje acontece, podia ser cantada de maneiras nem sempre totalmente coincidentes a depender do emissor, da zona ou do contexto até.

Convém salientarmos que algumas dessas amostras constituem na atualidade exemplos de cantares especialmente populares na maior parte do território galego. Como ilustrativo exemplo a esse respeito, podemos citar o caso dos conhecidos com o nome de "A saia de Carolina" - muito famosa não só na Galiza, mas também nas Astúrias, Leão e Portugal - ou a "Mariñada de Rianxo", dos quais Torre Enciso incluiu fragmentos das várias versóes que possuem (CTE, VI).

\subsubsection{A colaboração de terceiras pessoas}

Nas conversas com a família de Torre Enciso surgiu outro elemento a termos em conta como fonte de onde procederiam alguns materiais do Cancioneiro. Tal proveniência é a protagonizada por amizades e colegas do coletor que, sabedores do seu interesse pela literatura tradicional, lhe facilitaram o aceso a textos de extração anónima, quer em forma de apontamentos ou informaçóes - indicando-lhe que tal esta obra ou tal outra continha cantares transmitidos oralmente -, quer em forma de doação direta de textos. Lamentavelmente, torna-se tarefa impossível sabermos com exatidão quantas poesias puderam chegar às mãos do polígrafo galego através destas vias, ainda que, na linha do comentado em 2.3.3., achemos que é bastante provável que a existência

9. A compilação que também poderíamos considerar direta pode provir, às vezes, das lembranças que o coletor guarda a respeito de certos textos. Assim, nuns apontamentos que fez a várias poesias da área de Viveiro, os quais pudemos localizar cronologicamente na década de 50 ou 60 do passado século, lê-se o que se segue: "Este cantar que yo escuché en mi lejana infancia de hace cincuenta años, en Vivero, tambien es muy conocido en La Coruña, según investigué”. 
de versôes diferentes para um mesmo cantar ou refrão possa ser igualmente explicada graças a essa proveniência de terceiras pessoas. De qualquer modo, náo corresponde a este contributo aprofundar nessa via de pesquisa, a qual deverá necessariamente ficar para posteriores trabalhos.

\subsubsection{A literatura tradicional portuguesa}

Vejamos agora um traço que singulariza o CTE relativamente a outras compilaçóes. Uma notável quantidade de textos apresenta elementos lexicais e gramaticais hoje em dia mais próprios dos falares lusitanos do que dos galaicos. Desta forma, quer provenientes de obras dadas a lume, quer diretamente da oralidade, temos suspeitas para pensarmos firmemente que alguns cantares, a termos em conta os traços da linguagem com que se documentam, provêm dessas fontes. Em tais casos, Torre Enciso limitou-se a modificar a ortografia do português para a fazer coincidir com a do espanhol, base da atual norma ortográfica do galego ${ }^{10}$. Repare-se, assim, nas formas das primeiras persoas dos pretéritos do indicativo pus e quis, típicas do português, mas inexistentes nas modernas falas da Galiza conforme os estudos atuais de variação dialetal (cfr. Fernández Rei 2003: 98-99; ALGa 1990, I, 2: 622-623, 656-657): Ó pasar do ribeiriño / pus o pé, mollei a media (CTE, II); eu non a quis recoller, I foise con quen a levou (CTE, I); etc. Por enquanto, náo vamos dedicar mais tempo a estes assuntos porque mais adiante (\$3) desenvolveremos mais pormenorizadamente essas questóes.

\subsection{O âmbito territorial}

Mais uma caraterística do cancioneiro de Torre Enciso é aquela que nos leva a falarmos da sua adscrição geográfica. Várias são as tipologias de cancioneiros neste sentido: a primeira, quer selecionando quer compilando, tenciona recolher cantares de todo um país (CPP, CPGA, CPGAL, etc.), assim abrangendo diferentes regióes e temáticas e proporcionando uma amostra representativa de estrofes da maior parte de uma nação. A segunda modalidade é mais restrita e está motivada por questóes administrativo-culturais, pois centra-se numa determinada comarca, regiáo ou província (CPG, CPL, CPT, etc.). E a terceira das tipologias, que coleciona textos de todo o territorio, dedica-se a uma única temática particular, como o trabalho de Armando

10. Cfr. o assinalado pela própria Real Academia Galega na década de 70 do passado século: "A actual ortografía galega, como non podía menos de suceder, formouse sobre a castelá” [...]. Esta [a grafia do castelhano] preséntanos unha ortografía susceptible de perfeición, xa que non reflexa con suficiente precisión o vocalismo galego, e amosa algunha outra impropriedade como consecuencia de non ter xurdido naturalmente do fonetismo da fala, senón como unha adaptación da ortografía doutra lingua" (RAG 1970: 6-7). 
Cotarelo Valledor (CA), o qual recolhe textos centrados na figura das costureiras e dos xastres ou alfaiates no mundo tradicional, ou como a obra de Carme Hermida (PLM), que oferece uma representiva mostra de cantos provenientes de toda a Galiza, embora baseados em temas marítimos. Neste sentido, a coleção de Cipriano Torre Enciso encaixa na primeira das modalidades, visto não se enquadrar numa comarca, região ou temática concreta, mas abrangendo a totalidade do território e acolhendo, graças a uma classificação por eixos temáticos, uma grande diversidade de estrofes.

Ao mesmo tempo, dado que a proveniência dos cantares compilados por Torre Enciso obedece a tantas origens e dado que também os textos coligidos pelo intelectual corunhês não possuem qualquer tipo de referenciação territorial como é o caso de obras contemporâneas (CPG, CPGAL, CPP, LPG, etc), torna-se uma tarefa difícil ou quase impossível falarmos numa localização geográfica das estrofes ao não existir nenhuma indicação neste sentido; não se pode saber, portanto, em que regiáo, comarca, câmara municipal ou aldeia foram colecionados os textos. Contudo, uma olhada minimamente atenta a determinadas caraterísticas linguísticas das estrofes favorece em ocasióes repararmos em certas procedências geográficas; desta forma, os traços dialectais constatados em determinados cantares permitem atribuí-los, embora imprecisa e aproximativamente, a algumas zonas da Galiza: o advérbio eiqui (gal. com. aqui) e os pronomes il (gal. com. el) e aquil (gal. com. aquel), por exemplo, parecem fazer corresponder as quadras em que se documentam quer a comarcas aurienses, quer a áreas do sul da atual província de Lugo, seguindo o assinalado em Fernández Rei (2003: 69-72): traguede as gaitas, rapaces, / que os pandeiros eiquí están (CTE, IX); Zapateiro non o quero, / si mo dan, tiro con il, / que o quero carpinteiro / pra me divertir con il (CTE, V); Ó pasa-la ponte / de San Agustín, I aquil bicho negro I botábase a min (CTE, XIV); etc.

Outrossim, também contamos, na linha do exposto noutras secçôes deste trabalho $(\$ 1.3 ., 3)$, com a presença de textos portugueses, igualmente sem haver qualquer tipo de localização geográfica.

\subsection{A intervenção do editor}

Outro aspeto de interesse vem-nos dado pelas amostras em que Torre Enciso adotou algum tipo de medida para tentar aprimorar a qualidade linguística dos textos. A maior parte de pessoas que se dedicou à compilaçáo de cantares anónimos náo alterou, na base, os traços gramaticais e lexicais das estrofes, assim harmonizando com as indicaçôes de Emilia Pardo Bazán, quando, no nascimento da sociedade El Folk-Lore Gallego em 1881, não hesitava em escrever que "el mejor folk-lorista será el que menos ponga de su cosecha en los datos que recoja, el que respete las incorrecciones del lenguaje, las sencillas e ingenuas preocupaciones del vulgo y conserve más entero y desnudo el pensamiento popular" (BT 10). 
Os contemporâneos da escritora deixariam constância de terem assimilado muito bem essa maneira de fazer o trabalho de campo, como foi o caso de José Pérez Ballesteros, que clarificou que não pretendeu "corregir ciertas palabras y rarezas gramaticales, sino copiar con la fidelidad posible los cantos populares" (CPG II: 195, n. 1). Nos nossos dias, continua a praticar-se este procedimento, segundo se declara, por exemplo, na obra de Schubarth e Santamarina (1982: 24) quando se expóe que se tratou "de que as letras fosen unha mostra documental exacta da literatura oral de hoxe", renunciando-se assim "a galeguizar ou unifica-los textos". E também no recente trabalho de Díaz e Kirk Martínez (2012: 23) se assinala a vontade de respeitar os traços linguísticos dos cantares colecionados, refletindo-se "neles a forma de falar [...] tanto cos seus trazos dialectais [...] como por castelanismos e variantes propias do rexistro coloquial da lingua".

Porém, Torre Enciso, às vezes, levou a cabo como editor atuaçóes nos textos. Os casos que compóem essas alteraçóes certamente constituem um número variado, mas podem resumir-se do modo seguinte. Em primeiro lugar, temos de fazer menção à adaptação ortográfica e linguística de cantares tradicionais; isto pode explicar, por exemplo, que alguns espanholismos (relativamente) habituais nos cancioneiros galegos contemporâneos e na oralidade popular atual, como *amarillo (em vez de amarelo), *clavel (por caravel), * gallego (em lugar de galego), *iglesia ou *igresia (por igrexa), etc., não se documentem no CTE ainda que sim noutras compilaçóes ${ }^{11}$. No entanto, essa intervenção do coletor nem sempre foi assumida com coerência, já que existem textos a que lhes não aplicou nenhuma medida para lhes limpar as formas do castelhano, como se vê nas seguintes amostras: Adiós ó meu parabén! / Suspiros me fan a cama, / soledades me mantén (CTE, XIX); os casados valen prata, / os viúdos, calderilla (CTE, V); é un home moi capaz / de meter man ó bolsillo (CTE, IX); Marín pra boas sardiñas, / pra calamares Bueu (CTE, VII); Indo pola calle abaixo / escorrei nunha cereixa (CTE, VII); malas novas foran del / o dia que o conocín! (CTE, XIX); etc.

Em segundo lugar, transparece novamente a intervençáo do editor através da adoção de uma prática assaz recorrente no galego literário do século $\mathrm{XX}$, como foi a recorrência ao que nos trabalhos especializados se chamam de hipergaleguismos, hiperenxebrismos ou pseudogaleguismos. Assim, o coletor modificou palavras a que o percurso diacrónico lhes conferiu idêntica forma que as correspondentes do castelhano, convertendo-as nessas falsas formas inexistentes na língua oral. Embora já houvesse pontuais exemplos dos séculos XVII-XVIII em palavras como colúa (em vez de columna), primaveira (por primavera), etc. (cfr. Ferreiro 1997: 324, n. 501), tal procedimento principia, de acordo com o exposto em Freixeiro Mato, Sánchez Rei

11. Cfr. a sua atestação noutros cancioneiros: qu'está máis amarilliño / que a pela dun limón (CPG, III: 55); unha parece unha rosa / outra parece un clavel (CPG, II: 48); O canto d'o galleguiño / É canto que nunca acaba (LPG 53); Castellanos de Castilla, / estimai bên os gallegos (CO 167); Despedinme d'a igresia / e tamén d'o campanario (CPG, II: 117); etc. 
e Sanmartín Rei (2005: 716-728), a ser documentado com frequência em finais do século XIX, mas foi a partir da etapa do galego escrito denominada "galego enxebrista” por Fernández Salgado e Monteagudo Romero (1995) que se corroboram umas percentagens de uso certamente altas. Tudo isto permite entrever como era percebido determinado léxico por parte de Torre Enciso e como foi influenciado pelas modas vigorantes no galego literário da época. Por iso, não é de estranhar que no Cancioneiro também se atestem amostras como as que se seguem: *estranos (em vez de estraños), *brilar ${ }^{*}$ brilante (por brillar e brillante), * primaveira (em vez de primavera) ou * soma (em lugar de sombra): con unha augüińa que lava / tódolos males estranos (CTE, VI); Ti es a estrela máis linda / que no ceo vexo brilar (CTE, II); Primaveira, primaveira, I tempo de tomar amores; I non hai tempo máis brilante / que maio cas súas froles (CTE, II); Tedes un loureiro á porta, / tedes soma todo o ano (CTE, II); etc.

E em terceiro lugar, convém fazermos referência à presença de formas marcadamente arcaicas. Em sistemas literários normalizados, a recorrência a vocabulário e traços gramaticais considerados de outras épocas constitui um recurso estilístico de primeira ordem, pois assim é que se favorece "a evocação do passado, a recriaçáo de uma atmosfera solene ou pitoresca", segundo Martins (2000: 85). Daí que determinadas correntes estéticas que valorizavam os factos históricos concedessem a entrada a essas caraterísticas linguísticas: "poetas e romancistas do Romantismo, que procuraram reviver os tempos medievos, valeram-se de numerosos vocábulos colhidos em velhos documentos", conforme continua a salientar a professora Martins. No caso particular da Galiza, acompanhando o exposto em Freixeiro Mato, Sánchez Rei e Sanmartín Rei (2005: 677-682), em finais do século xIx, e graças ao descobrimento e posterior conhecimento dos textos galego-portugueses medievais, os escritores e as escritoras vão dispor de uma fonte de enriquecimento linguístico inexistente até à época, que, para além de contribuir para o acrescentamento lexical, serve aliás como um importante elemento prestigiador da língua e da literatura. Ao participarem também da vontade diferencialista antes assinalada, as pessoas que protagonizam o particular renascimento literário oitocentista foram utilizadoras de vozes como cibdade, conquerir, etc., ou de grafías arcaizantes como azúes, boo, door, cristaes, floraes, teer, etc. Estas recorrências a léxico antigo e a práticas ortográficas de inspiração medieval mantiveram-se, com diferentes intensidades, até ao processo de elaboração do padrão desenvolvido nas décadas de 70 e 80 do século xx.

Desta forma, quer pela época em que foram compilados os materiais do CTE, quer pela situação da linguagem literária a que pôde ter acesso Torre Enciso - a qual continuava a recorrer estilística e diferencialmente ao idioma medieval -, o certo é que aparecem nas poesias do Cancioneiro grafias que nos transportam a outros séculos. Neste sentido, o facto de o coletor ter contato com escritores e académicos galegos, dada a sua pertença como membro correspondente à RAG, pode estar em relação com a presença dessas formas de rosto antigo. É verdade que, no seu conjunto, não constituem um número representativamente abundante, mas contudo é merecente 
de nota por se atestar numa modalidade linguístico-literária afastada de qualquer moda estética de caráter arcaizante. Assim, para além da frequentíssima recorrência à forma nascer (e também, ainda que em menor medida, às mais esporádicas crescer, descir, merescer, padescer, renascer, etc.), registam-se algumas palavras vernizadas com óleos medievais, insólitas ou absolutamente residuais nos cancioneiros clássicos contemporâneos: lévame nas túas aas / unha carta ó meu amor (CTE, II); naquela hora tan negra / tres veces bateu as aas (CTE, XVII); Cibdade de Compostela, I onde se forman doutores (CTE, I); Teño corrido mil terras, / cibdades, máis de coarenta (CTE, II); eu non te vexo morrer; quen morre perde a coor (CTE, XIII); Mociña, ten compasión / ten door e ten piedade (CTE, XV); Por unha noite de gosto, / nove meses de door (CTE, II); Levaremos un guedello / tan solo das nosas laas (CTE, IX); etc. ${ }^{12}$

Por outro lado, temos de lembrar aqui que o cancioneiro tradicional foi recorrentemente empregue para o estudo de variedades rurais e dialetais da língua. Assim, já desde os primórdios do século xx, Vasconcellos $(1928,1985)$ acudiu a ele de forma a ilustrar os fenómenos fonéticos, lexicais ou morfossintáticos que pôde recolher nos seus trabalhos de campo e chegou a ponderar que é "em textos populares que melhor se pode apreciar a linguagem do vulgo, com todo o seu colorido emocional e ao mesmo tempo a sua naturalidade simples" (1928: 77). Também existem obras contemporâneas em que se salienta esse tal valor: Nunes (1975, I: XII), por exemplo, expôs que nas composiçôes da lírica tradicional "encontrará o filólogo vasto material para estudos concernentes a características linguísticas de variadas regióes portuguesas”, enquanto já mais recentemente Mariño Paz (2017: 99) assinala como a literatura de transmissão anónima corresponde a uma "fonte moi recomendable para o estudo das variedades rurais do galego nos últimos douscentos anos". Porém, a intervenção do autor que vimos referindo nesta secção invalida de alguma forma uma parte desse valor dos textos anónimos. Tratando-se, em si própria, de uma atuação louvável no sentido de o coletor tentar aprimorar a língua dos cantares, provoca, em confronto, que precisamente as poesias tradicionais percam qualquer coisa da sua validade como ferramenta capaz de nos informar sobre os traços gramaticais e vocabulares de um modelo particular de linguagem popular e dialetal.

Com todos os matizes necessários, o tipo de língua que aparece no Cancioneiro de Torre Enciso não difere muito do empregado no seu poemário Panxoliñas, dado a lume pela primeira vez em 1956, no qual também se aprecia certa vontade de utilização de um galego o mais genuíno possível, mercê à incorporação de pseudogaleguismos ou de formas marcadamente arcaicas, dialetais ou populares, mas todas elas di-

12. Torna-se pertinente salientar a seguinte estrofe pela documentação, verificada pela rima, de ren, 'nada', arcaísmo recuperado na Galiza na época do Seminário de Estudos Galegos, que chegou, por causa do grande sucesso literário e pelo diferencialismo face ao espanhol, a figurar na proposta de variedade padrão como mais um integrante do paradigma de pronomes quantificadores (cfr. RAG/ ILG 2003: 97): Somos primos e mais ben;/ xuntaremos o diñeiro / que a dispensa vén a ren (CTE, III B) 
ferentes do espanhol: Calma na carpinteiría (PA 14), d’unha gran carniceiría (PA 43), Non me abandoes (PA 19), Un groulo nas túas mans (PA 53); asi remata esta hestoria (PA 43); Dende que che vín meu Neno / antr'a vida e morte peno (PA 27); lembran o agasallo / diste pecoreiro (PA 23); non deixés o torno / pra ir ô seu Tempro (PA 17); etc. E também não estão sem exemplo soluçóes consideradas arcaicas: palilleiras dos azúes (PA 25); Xesús tamén nasce / na cunca dos púcaros (PA 17); etc.

Voltando ao início desta parte e a modo de conclusão, tudo isto, em definitivo, abre a porta a formularmos duas perguntas linguística e literariamente de interesse. A primeira delas assenta à volta de em que medida a língua transmitida pelo CTE é decerto util para nos aproximarmos do galego e do português em registos dialetais e populares, tendo em conta as vezes em que se deteta a intervenção de Torre Enciso. A resposta a esta questáo vem dada caso se tivessem em conta as ocasióes em que se verifica a tal prática, pois, no seu conjunto, torna-se um número menos representativo do que aquele em que a atuaçáo propositada do editor não foi capaz de eliminar traços marcadamente populares ou locais dos cantares coligidos no Cancioneiro, como se verá mais abaixo (\$3.1.).

A segunda pergunta, dado que Torre Enciso também foi autor de textos em galego, centra-se na possibilidade de considerarmos o CTE como uma obra de presumível elaboração estética e literária, sobretudo considerando a intervenção nos textos do polígrafo corunhês. A pertinente resposta a este assunto faz-se merecente de uma extensão que por motivos de espaço não pode ser desenvolvida aqui. No entanto, pode ser formulada de modo provisório assumindo como duvidosa tal consideração ou perspetiva; note-se, a este respeito, que as poesias de extração tradicional estão normalmente condicionadas por umas caraterísticas, temáticas rímicas e rítmicas muito particulares, as quais nem sempre encontram os mesmos condicionalismos nos textos de autoria individual ao estes estarem muito mais subordinados à vontade estética do autor ou da autora que os opúsculos de proveniência anónima.

\section{Galego e português no CTE}

\subsection{A língua dos cancioneiros, uma variedade popular}

O conjunto de cantares coligidos por Torre Enciso apresenta, do ponto de vista linguístico, uma série de caraterísticas que o vincula a outras coleções de similares finalidades, mas também possui diversos traços, não presentes noutros cancioneiros galegos, que fazem com que esta obra constitua um caso singular relativamente ao tipo de língua que se documenta nos textos. Antes de mais, convirá precisarmos que o galego transmitido no CTE recebe com muita facilidade o qualificativo "popular", fundamentalmente pelos seguintes motivos. Em primeiro lugar, as camadas sociais que produziram e que geraram esse tipo de textos anónimos eram fundamentalmente 
populares, afastadas ou varridas do mundo académico e caraterizadas pela sua adscrição maioritária às classes menos favorecidas, o que corresponde linguisticamente ao que se denomina variedades diastráticas. Falamos, pois, em certos tipos de gentes do artesanato, camponesas e marinheiras, provenientes do mundo rural ou suburbano, que representavam, em finais do século XIX e nos primórdios da centúria seguinte, uma percentagem de populaçáo que oscilaba à volta de 80-90\% (cfr. Calo Lourido et al. 1997: 303; Freixeiro Mato / Sánchez Rei \& Sanmartín Rei 2005: 57). E referimo-nos também ao facto de a maior parte desses cantos ser transmitida por mulheres, como, no geral, continua a acontecer mesmo na atualidade.

Em segundo lugar, os contextos em que se transmitiram ou em que se criaram esses textos eram familiares ou coloquiais, sobretudo a pensarmos no tipo de situaçóes em que se produziam, assunto que nos leva a falarmos em variedades diafásicas. Estamos a referir-nos a reunióes como os fiadeiros noturnos, certo tipo de lavores e trabalhos coletivos, etc., nada próximos, pela sua idiossincrasia, de contextos dotados de maior formalidade. Eis onde cobrou sentido uma virente cultura tradicional durante a Idade Moderna e a Contemporânea, alheia em muitas das suas manifestaçôes aos rigores da reforma tridentina e às constantes reaçóes pedagógicas das hierarquias eclesiásticas, conforme expóe Saavedra (1992: 218).

Subsequentemente, em terceiro lugar, não existia na época em que se geram todos esses cantares (quando menos desde o século XVII até a uma boa parte do Xx) um modelo de galego oral que não fosse fundamentalmente popular, pois populares eram os grupos sociais que o falavam, populares eram igualmente os tipos de pessoas que produziam e transmitiam essas estrofes e populares eram também as mais das situaçóes em que se empregava; náo havia, pois, todas as modalidades de língua oral que Monteagudo (2005: 420-422) chega a contabilizar para a atualidade, ainda que se pudessem detetar diversos níveis de hibridação com o espanhol, já notados desde os eruditos setecentistas e oitocentistas.

E em quarto lugar, a transmissão desses cantares, tanto pelos agentes que a fizeram possível quanto pelas situaçóes em que se desenvolveu, não primou a vontade estética vinculada a uma - na altura - inexistente variedade padrão nem a correntes literárias acentuadas pelas modas artísticas internacionais. Contrastivamente, esteve orientada (i) pela expressividade popular, mantida e apreendida de geraçôes em geraçôes e vernizada com um denso óleo de elementos linguísticos dialetais e locais; (ii) por umas temáticas muito concretas emanadas diretamente do modo de vida dessas gentes; e (iii) por uma funcionalidade sócio-cultural muito concreta que carateriza essas tais manifestaçôes poético-musicais hoje, com a relevância da vida urbana em detrimento da rural, totalmente em crise (cfr. Blanco Pérez 1994: 164).

Em termos mais específicos, já de uma perspetiva linguística e de acordo com os quatro pontos que acabam de ser expostos, o tipo de língua em que se veiculiza o cancioneiro tradicional galego e particularmente o coligido por Torre Enciso vai facilitar a atestação de fenómenos hoje considerados idiossincraticamente populares, de traços 
que dizem respeito à variação dialetal e de exemplos de erosão causada pelo espanhol. Aparece assim uma representativa mostra de uma variedade linguística definitória deste tipo de expressão artística (com a exceção, já comentada mais acima, dos casos em que o editor modificou propositadamente a língua). Mas, igualmente, o CTE, apresenta um elemento que o singulariza a respeito de outras compilaçóes, como é o facto de, ainda dentro dessa caraterizaçáo geral que acabamos de formular, servir como exemplo da presumível incorporação de cantares tradicionais portugueses. E desta questão é que vamos tratar a seguir.

\subsection{Consideraçôes gerais}

Os eruditos galegos e portugueses começaram já na segunda metade do século XIX a salientar a identidade linguístico-cultural que percebiam nos cantares anónimos galaicos e nos lusitanos ${ }^{13}$. Na verdade, não se torna difícil tracejarmos linhas de confluência entre ambos: em primeiro lugar, temos o contínuo territorial com que se significam a Galiza e Portugal e a essencial unidade linguística galego-portuguesa, conservada também em registos coloquiais e populares da língua (cfr Sánchez Rei 2008), como são os que servem para caraterizarem as variedades empregadas na poesia tradicional, de acordo com o exposto em 3.1. Em segundo lugar, é preciso salientarmos a elementar comunidade cultural e etnográfica que apresentam os dois países, nomeadamente entre os atuais territórios galegos e as províncias setentrionais portuguesas do Minho e Trás-os-Montes; isto já foi defendido, entre outros, por Fernando de Castro Pires de Lima (1932) no seu trabalho "Afinidades galaico-minhotas do cancioneiro popular", opúsculo em que deixou escrito que surpreendia "a quasi identidade entre a poesia popular galega e a portuguesa", até ao extremo de que, com "pouca diferença, se canta, quer no Minho, quer na Galiza, o mesmo Cancioneiro" (Lima 1932: 240). E, em terceiro lugar, não nos podemos esquecer dos contatos culturais, económicos, laborais, pessoais, etc. que sempre existiram entre as comunidades rurais das duas margens da fronteira administrativa, o que ainda se viu favorecido pelo facto de muitos galegos emigrarem para as grandes cidades portuguesas durante os séculos XVIII e XIx. De tudo isto era muito consciente Lorenzo Fernández (1973: 20), que, a comentar alguns traços culturais e históricos da regiáo da Límia na sua parte galega, se exprimia do modo que se segue:

13. Assim o fizeram no seu dia Theóphilo Braga (1843-1924) no prólogo ao CPG editado por José Pérez Ballesteros (1833-1918), Juan Antonio Saco Arce (1835-1881) em LPG em finais do século XIX, Fernando de Castro Pires de Lima (1908-1973) na segunda metade do século xx, Xoaquín Lorenzo Fernández (1907-1989) nas anotações ao CPL, etc. É também merecente de se salientar o poeta Manuel María (1929-2004), que, nos anos noventa do passado século, afirmou que lhe parecia certamente surpreendente a identidade do cancioneiro galego e o português (AT 144). 
A fronteira da nosa comarca con Portugal polo Sul e polo W. xustifica ben a intensa relación co país irmán. Son moitas as xentes limiás que acoden de cote a certas romaxes e festas de Portugal, especialmente á Nosa Señora da Peneda, ao Bom Xesús de Braga, ás festas da Vila da Barca, Lindoso, etc., do mesmo xeito que veñen os portugueses á Nosa Señora da Clamadoira, á Virxe do Xurés ou ás festas de Entrimo e Lovios.

Por outra parte, moitos dos homes de por aquí, especialmente de Calvos de Randín, Lovios e Entrimo, van traballar a Portugal, sobre todo a Porto e Lisboa e voltaban á terra ao xuntaren algún dińeiro.

Todos iles van de vehículo de influencia de unha terra na outra, facilitando iste intercambio e semellanza de vida e traballo de Galicia e do Norde de Portugal, aparte, craro está, da identidade idiomática.

Essas "semellanza" e "identidade idiomática" que marca Xoaquín Lorenzo Fernández, portanto, facilitam que se possa falar, em termos gerais, de um cancioneiro popular galego-português dentro de um mais amplo ou hispânico, logicamente com as subsequentes e expetáveis caraterísticas linguísticas, formais e temáticas de cada território particular. Tanto é assim que, do ponto de vista sociolinguístico, e retomando uma das ideias de Fernando de Castro Pires de Lima, se deteta em certas ocasióes a mesma poesia nas duas margens minhotas e, não raro, aparece nas comarcas galegas, com interferências lexicais que não se encontram nas equivalentes portuguesas: ao passo que na Galiza se atestam com muita frequência formas como *adiós, *amarillo, *calle, *estuvemos e *tuvemos, *luna, *ventana, etc., em Portugal figuram com as legítimas adeus, amarelo, estivemos e tivemos, rua, lua, janela, etc. (cfr. Sánchez Rei 2006: 352).

Ao mesmo tempo, umas quantas poesias cantadas na Galiza têm origem portuguesa ou, pelo menos, essa foi a impressão a que chegaram alguns coletores. Em vários trabalhos contemporâneos galegos tem-se identificado a procedência lusitana para determinados textos tradicionais: traços linguísticos e assuntos desenvolvidos inspiraram um autor como Juan Antonio Saco Arce a salientar essa possível proveniência para determinadas estrofes a afirmar que a linguagem "hace sospechar que es de origen portugués" (LPG 78, n. 89). E, igualmente, umas poucas caraterísticas linguísticas de certas quadras coligidas por Nicanor Rielo Carballo no sul da província de Lugo (i.e., dois, faminto; gal. com. dous, famento; EC 137-138) fizeram com que o editor não hesitasse em ponderar que vários dos textos do seu cancioneiro eram de "procedencia portuguesa".

Com tais antecedentes, em congruência com o exposto mais acima ( $\$ 1.3 .4)$, o cancioneiro tradicional português não foi alheio a Torre Enciso. O tratamento que recebe, quando menos em aparência, um cumprido número de cantares tradicionais portugueses assenta numa das mais notáveis caraterísticas do CTE, como foi a vontade de procurar a simbiose entre os cantos galegos e os provenientes da outra 
margem minhota. Assim, o compilador parece dar mais um passo de forma a avançar nessa comum identidade a que faziam referência Fernando de Castro Pires de Lima ou Xoaquín Lorenzo e, partindo do extraordinário valor desse contínuo cultural, decide adaptar ortográfica e, às vezes, linguisticamente, estrofes lusitanas; a consabida proximidade ou identidade linguística entre a Galiza e Portugal e as náo poucas confluências temáticas no cancioneiro galego e português parecem ser as responsáveis destas atuaçôes.

Mas, sabermos quantas obras portuguesas de literatura tradicional manejou Torre Enciso ou a que autores acudiu é uma pergunta que por enquanto não pode ter resposta. Muito possivelmente, o polígrafo conhecesse os trabalhos de José Leite de Vasconcellos ou o seu cancioneiro (CPP). Verificámos, contudo, que um considerável número das cantigas coligidas por Torre Enciso encontra as suas equivalências nas quadras do Cancioneiro Popular Transmontano e Alto-Duriense, editado por Felgueiras em 1966 (CPT), só com pequenas mudanças ortográficas ou com alteraçóes de outra índole que não as convertem em estrofes diferentes. Por isso, com todas as reservas necessárias, não descartamos que o erudito galego empregasse esta obra, entre outras possíveis ${ }^{14}$, para incorporar tais cantares. Repare-se a esse respeito nas seguintes composiçóes:

a)

Cuidavas, por me deixares

Qu'eu de paixão morreria;

Foi-se un amor, voltou outro,

Vivo na mesma alegria!

(CPT 218)

b)

Cuidavas, por me deixares

Que por ti perdia a cor;

Cada vez mais còradinha

Para arranjar outro amor!

(CPT 218)

c)

Algum dia nesta rua

Tinha eu minha cadeira

Agora, passo por ela

Como a lebre na carreira.

(CPT 212) a')

Coidabas, por me deixares,

que eu de paixón morreria;

foise un amor, voltou outro,

vivo na mesma alegría!

(CTE, I)

b’)

Coidabas, por me deixares, que por ti perdia a cor; cada vez máis coradiña para arranxar outro amor! (CTE, I)

c')

Algún día nesta rúa

tiña eu miña cadeira;

agora, paso por ela

como a lebre na carreira.

(CTE, I)

14. Pensemos, conforme nos participou a família, na notável presença de obras portuguesas na sua biblioteca particular. 
d)

Não há Sol como o de Maio,

Nem luar com'o de Janeiro,

Nem cravo com'o regado,

Nem amor com'o primeiro.

(CPT 16)

e)

Não há sábado sem Sol,

Nem alecrim sem flor;

Não há menina bonita

Que não tenha o seu amor.

(CPT 16) d')

Non hai Sol como o de maio,

luar como o de xaneiro,

caravel como o regado

nin amor como o primeiro.

(CTE, XII)

e')

Non hai sábado sin sol

nin rosaleda sin frol;

non hai neniña bonita

que non teña o seu amor.

(CTE, XII)

Por vezes, perante estas amostras, assaltam-nos as dúvidas de se na realidade Torre Enciso versionou um cantar tradicional português para o galego ou, pelo contrário, de se se trata de textos comuns nos dois territórios com as singularidades linguísticas típicas de cada país. No entanto, noutras ocasióes, essa adaptação a que se veem submetidos os versos não é capaz de manter com fidelidade as caraterísticas fonéticas ou morfológicas dos cantares de procedência lusitana. Tal é o que se verifica nas duas seguintes estrofes, em que a rima V2-V4 não consegue conservar-se ao passar, no primeiro caso, de uma possível simetria dão - coraçâo a dan corazón e, no segundo, de rapaz - faz a rapaz - fai:

\author{
$A$ da banda non a quero, \\ a do meio non ma dan; \\ quero a máis bonitina \\ que me alegra o corazón. \\ (CTE, I) \\ Eu andaba de namoro, \\ roubáronme o meu rapaz; \\ roubáronme un, teño dous, \\ olla a falta que me fai! \\ (CTE, I)
}

Não estão sem exemplo presumíveis incorporaçôes de estrofes em que a ortografia delata tanto a origem lusitana quanto o manejo de bibliografia dos primeiros anos do século Xx, antes das reformas ortográficas desenvolvidas por Manuel Gonçalves Viana a partir de 1911. Com efeito, com anterioridade a esta data, no marco 
do particular poligrafismo que caraterizou a escrita portuguesa nos séculos XVIII e $\mathrm{XIX}$, os plurais das palavras acabadas em - al respondiam à solução gráfica animal $\rightarrow$ animaes, em que -aes se pronunciava no padrão igual que se fosse grafado - ais (['ajf]). Por isso, quando achamos no CTE exemplos como os que vamos expor a seguir, em que parece que nos encontramos perante a representação antiga desses plurais, somos proclives a pensar, mais uma vez e com maior firmeza, na recorrência de Torre Enciso ao cancioneiro português e em particular a obras anteriores a 1911, muito embora não adaptasse esses pormenores gráficos: $A$ silva enreda as paredes, I a heradeira, os quintaes; / eu ben enredada ando / nos teus suspiros e ais (CTE, I); Os teus beixos son ardentes, / penetran como puñaes; / si me apuñalas con beixos, / eu morro pedindo máis (CTE, II); Miña cereixa bical, / picadiña dos pardaes, / a quen deches os biquiños / dálle tamén o demais (CTE, XV); etc.

Chegados a este ponto, podemos formular a seguinte pergunta: que elementos linguísticos insinuam com bastante dose de verossimilhança que o coletor acolheu no seu Cancioneiro textos da literatura tradicional portuguesa? Para darmos conta desta questão, acudimos apenas a uns poucos fenómenos de natureza morfossintática e vocabular, sabedores de que darmos conta de todos eles exigiria um trabalho mais extenso.

\subsection{Alguns aspetos gramaticais}

\subsubsection{Sufixos e terminações}

Em primeiro lugar, no CTE aparecem alguns exemplos esporádicos dos antigos -són e -zón: Eu quero, cando morrer, / levar de recordazón (CTE, XIII); Eu hei de casar contigo, I si o casamento é prisón (CTE, V); Pola mañán, vento á terra, / pola noite, virazón ${ }^{15}$ (CTE, V); os fillos o tarangaño, I mirade que perdizón! (CTE, VII); Si coidas que estou por ti, / ben te engana a presunzón (CTE, II); etc. A sua atestação no galego contemporâneo fez com que na literatura especializada se tornasse num dos temas mais recorrentes relativamente à época em que desapareceu da linguagem corrente, à sua possível incorporação à linguagem culta, etc. Achamos que a sua documentação nas estrofes deve ser relacionada ou bem com uma atuaçáo deliberada do coletor, influída talvez pelo galego literário do século xx, em que se fizeram tentativas formais de recuperaçáo de tais sufixos no âmbito da Real Academia Galega ${ }^{16}$, ou bem com

15. Virazón (ou viração na norma lisboeta) é uma das possibilidades galego-portuguesas de nomenclatura para o nome maré, ambos sujeitos a certa distribuição geográfica quando menos no século XviII, segundo indicava Jerónimo Contador de Argote (cfr. Castro 1991: 43).

16. Cfr. Freixeiro Mato (2017: 69-71), que se centra na figura do académico Leandro Carré Alvarellos, firme defensor dos sufixos tradicionais. 
uma adaptação a partir do português. Uma presumível sobrevivência deles é outra hipótese, mas não nos parece tão plausível: de acordo com alguns trabalhos modernos (cfr. Ferreiro 1997: 140; Mariño Paz 2003: 186-190; etc.), estas terminações chegaram até ao século XIx, época na qual, muito provavelmente pela influência do espanhol, deixaram de ser comuns ${ }^{17}$.

No tocante ao verbo, uma primeira leitura do Cancioneiro já ilustra sobradamente a complexidade morfemática e sintática daquele. Principiando por aspetos morfemáticos, se o género serve para classificarmos os nomes em masculinos e femininos, a vogal temática (VT) age para identificarmos os verbos em três conjugaçôes: - ar $(\mathrm{CI})$, - er (CII) e -ir (CIII). No seu conjunto, não se apreciam no CTE desviaçóes desta tripla divisão relativamente ao galego contemporâneo, de modo que as formas verbais detetadas nos materiais de Torre Enciso encaixam nesse agrupamento trimembre. Porém, há algumas exceçóes a esta tendência geral no respeitante à consideração de verbos, quer da segunda, quer da terceira conjugação e uma delas é a que se verifica para dicir, que aparece como dicer nalgumas ocasióes: súa Nai lle está dicendo: / "Fillo meu e moi amado" (CTE, IX A); a do medio vai dicendo / -A guindeira non ten máis! (CTE, II); Escoitai, que queremos dicer / duas palabrinas ou tres (CTE, IX B), etc. Nestes casos em particular, e ainda que alguns cancioneiros contemporâneos (CMG, CO, CPG, PGA, etc.) também recolhem estrofes com as variantes dicer ou decer (cfr. Carballo Calero 1980: 205; Sánchez Rei 2016: 264-265), hoje em dia sentidas como formas locais ou literárias, achamos que novamente se trata de possíveis adaptaçóes de quadras portuguesas a termos em conta que as poesias incluídas no CTE se não atestam nos cancioneiros galegos. Por último, temos de acrescentar que náo supóe este o único caso de verbos que aparecem no cancioneiro com uma VT distinta da que na atualidade se considera mais habitual ou padrão. Assim, contamos com os testemunhos de receber, perceber e escreber, considerados presentemente literários ou dialetais ${ }^{18}$ : pra receber os biquiños / con que o vais adelgazando (CTE, XI); Preguntei

17. Dado o simbolismo que estes sufixos trouxeram consigo no debate normativo de finais do século $\mathrm{xx}$, temos de citar aqui que, esporadicamente, se documentam nalguma coleção de literatura tradicional oitocentisa (Adiós que che me embarco / N-a primeira embarcazón, LPG 72), o que parece converter-se em mais um argumento para pensarmos em certa rendibilidade desta partícula na altura, ainda que a tal rendibilidade já estivesse num progressivo e avançado processo de desaparecimento.

18. Cfr. Ferreiro (1999: 281-282), quando assinala que no "galego moderno existen certas vacilacións na adscrición dalgúns verbos á segunda ou terceira conxugación, observándose na lingua popular unha tendencia favorábel á terceira, somente freada pola utilización literaria das formas máis tradicionais". Também expóe este investigador que "a interferencia do español condiciona tanto os usos populares como, en moitos casos, a selección literaria das formas utilizadas na lingua común, especialmente en verbos coa estrutura normal [e...ér] (conceber, escreber, perceber, receber, etc.), nos que, na nosa opinión, os cambios deben ser explicados pola intensa e duradoira presión do espańol, a pesar de que algún destes verbos xa presenta no derradeiro período medieval (precisamente cando comeza a colonización lingüística da Galiza) formas da terceira conxugación (escrevir ou escrivir, por exemplo)". 
ó Sol si viu, / á Lúa si percebeu (CTE, II); na folla da urce se escrebe / e aínda fica por encher (CTE, II); etc.

Deixando de lado a VT, merecem comentário singular as variantes do MNP da P2 -che, -ches, -ste e -stes. Do ponto de vista dialetal, registam-se no território galego todas elas, embora numas proporçóes diferentes: ao passo que -ches conhece uma maior atestação, sobretudo nos falares centrais e ocidentais, -che acrescenta a sua frequência de aparecimento conforme se avança do galego atlântico para o oriental. Por sua vez, -ste e -stes são típicas de falares ocidentais, ainda que minoritárias se comparadas com as variantes anteriores (cfr. Fernández Rei 2003: 87-88): a primeira é caraterística do Baixo Minho galego, enquanto a segunda pode achar-se nas regióes de Fisterra, Soneira, Barbança e Arousa ${ }^{19}$. No entanto, apesar desta distribuição local minoritária, surpreende a notória presença de exemplos com que aparece no Cancioneiro, o que, mais uma vez, julgamos que pode ser atribuído à vontade do coletor de incorporar textos portugueses: Acenásteme do adro / cun lenzo de meia vara (CTE, I); Cando te amaba, fuxiste, / agora dásme alma e vida (CTE, I); Chamásteme moreniña, / mírame ben para os ollos (CTE, I); Rapaciña do meu tempo, / chamásteme a min rapaz (CTE, VII); etc. Aliás, no cancioneiro não estão sem exemplo estrofes em que se documenta tanto as variantes morfológicas mais gerais no galego, -che ou -ches, quanto a habitual no português, -ste, o que quiçá deva ser entendido como mais uma adaptação parcial, que tem como consequência, nalguns casos, a perda da simetria rímica consonântica: Deiche un bico e ti coraste, I deiche outro e ti sorriste; / os máis que te teño dado / fuches ti quen mos pediches (CTE, II); Ti mandásteme eiqui vir, / ó pe do piñeiro manso; I eu vin e ti non viñeche, I xa non son o teu descanso! (CTE, II); etc.

Vejamos agora outras desinências verbais, como os MNP da P5 do gal. com. -des, $-d e$, formas do presente do indicativo e do imperativo, respetivamente. De uma perspetiva local, registam-se na atualidade as formas cantais, cantandes, cantás e cantades, de acordo com Fernández Rei (2003: 90): a primeira ouve-se no galego oriental e em falares do Baixo Minho, a segunda atesta-se no extremo ocidental do sul da província de Pontevedra e no sul de Ourense, a terceira na regiáo da Costa da Morte e a quarta, a maioritária, documenta-se no resto do país; a respeito do imperativo cantai, cantande, cantá e cantade, em harmonia também com este investigador, correspondem tais resultados às mesmas áreas e zonas que as anteriores, ainda que no "sur de Pontevedra e na maior parte de Ourense" é possível achar um imperativo cantai. O Cancioneiro proporciona uma cumprida mostra da maior parte destas soluçóes: Canteiros de Pon-

19. É provável, no entanto, que, sem se modificar na base o estado dialetal do galego contemporâneo, nalgumas comarcas fosse tendo mais vigor ora -che, ora -ches, ou mesmo que uma das duas fosse deslocando vários quilómetros e invadindo o território da outra ou mesmo a variante mais conservadora -ste; esta aparece residualmente noutros cancioneiros de finais do século XIX em áreas em que presentemente se torna impossível a sua documentação: Si ves por adivirtirte, / galanciño, ben fixeste; / si non sabes o camiño / vólve por onde viñeste (CPG I, 89). 
tevedra, I onde estades ben vos vedes (CTE, V); Miñas ánimas benditas / que estades ó pé do río (CTE, VI); xa que me dades amores, / dádeme sorte con eles (CTE, VI); $A i$, rapazas de San Finz, I que facés, que non casás? (CTE, V); Cantá, cantá, paxariños, I que eu tamén moito cantei (CTE, VI); -Casaime, meu pai, casaime (CTE, V); Miña nai casaime cedo, I a cousa ben a sabeis (CTE, V); Pra que chorais, tristes ollos, I pra que me dais tanta pena, / pra que me estais relembrando (CTE, II); Polos ollos que deitais I sei o ben que me quereis (CTE, II); etc.

No entanto, relativamente a estes morfemas, é surpreendente o número de estrofes em que se documentam as soluçôes mais inovadoras cantais, cantai, também comuns com o português, o que nos leva a pensarmos na possível adaptação que pôde ter feito Torre Enciso a partir de cantares do sul do rio Minho. Nestas amostras, a presença de elementos lexicais ou gramaticais caraterísticos ou mais frequentes que no galego (i.e., dicer, amañán, etc. / port. com. dizer, amanhä, etc. / gal. com. dicir, mañá, etc.) parece verificar, nos casos em que figuram, a tal procedência: Escoitai, que queremos dicer / duas palabriñas ou tres (CTE, IX B); Mozas, non faleis das mozas, / son mulleres coma nós! / Hoxe estais a falar delas, / amañán elas de vós! (CTE, XVII B); etc.

\subsubsection{Particularidaes dos verbos irregulares}

Outrossim, dentro da classificação dos verbos em regulares, semi-regulares e irregulares, caraterizam-se estes últimos por apresentarem importantes alteraçóes no morfema lexical, em especial no tema de pretérito. Ao mesmo tempo, também se encontram variantes locais nalguns casos (como o que acontece com poder: puid-, poid- e pud-; pór: pux- e puñ-; traer: troux-, trux-, troix- trui-, tru-, troug(u)-; etc.), o que confere a esta tipologia de verbos uma notória complexidade morfemática de natureza diatópica, diafásica e diastrática. Para o caso de alguns deles, o Cancioneiro de Torre Enciso proporciona um outro tipo de variantes, novamente a transparecer a proveniência de Além Minho. Sintetizando os exemplos que pudemos constatar, teria de se falar em dois tipos: em primeiro lugar, as relativas ao tema de pretérito de querer, sem dúvida o mais documentado dentro destas particularidades (eu non a quis recoller, I foise con quen a levou, CTE, I; Toda a vida quis e quero / a filla dun labrador, CTE, II; serei túa, serei doutro, / serei de quen eu quiser! (CTE, I); ama ti a quen quiseres / que eu xa teño quen me queira; CTE, II; etc.); e em segundo lugar, no tema de pretérito de pór (Pusme a chorar ó pé da auga / lágrimas de sentimento, CTE, XVII B; Pusme a contar as estrelas / naquelas noites divinas, CTE, II; etc.).

Igualmente, com menos atestaçóes, os pretéritos de outros verbos irregulares, normalmente nas suas primeiras pessoas, também protagonizam esses traços morfemáticos: Eu queríame casar / e meu pai dis: "Pouco a pouco" (CTE, XVI); Funme a confesar e dixe / que non tiña amor ningún (CTE, I); dunha nuben fixe a cama, I din un beixo a unha estrela (CTE, II); Onte á noite, por meu gosto, / fixe un pecado mortal 
(CTE, V); non as pude dar contadas (CTE, VII); Soiña, lonxe do mundo / nunca soube $o$ que foi o amor (CTE, XIX); Namoreime, namoreime, / mais non soupe namorar (CTE, XV); Caseime con muller vella / por causa da fillarada; / olla o diaño da vella, I tive dez dunha niñada! (CTE, V); Esta noite tive un soño, I que me morreu o meu ben (CTE, X); No campo vin unha viña / e trouxe un ramo de uvas (CTE, XV); toda a vida trouxe e traio / toda a muller engañada (CTE, I); etc.

Para a explicação de todas estas formas podemos pensar em várias possibilidades, ainda que, a nosso ver, a mais recorrente seja aquela que, mais uma vez, tem em conta o cancioneiro tradicional português como origem desse polimorfismo, sobretudo reparando na total falta de documentação na oralidade galega de formas como dis, pus ou quis ${ }^{20}$. Noutros casos, porém, não se pode rejeitar que uma transmissão oral defeituosa ou uma adaptação não totalmente conseguida do português esteja na verdade atrás de formas como dixe, fixe ou puxe. Outras explicaçóes, como uma hipotetica origem dialetal de formas minoritárias tipo dixe, quixe, trouxe (cfr. ALGa, 1990 I, 2: 452-453, 656-657, 748-749), típicas dalguns pontos do galego oriental localizados na província de Leão, não nos parecem defendíveis.

Por outro lado, no que se refere ao presente do indicativo do verbo ser, as particularidades mais notáveis focam-se na documentação no CTE das formas de P1 son e sou, a primeira geral na Galiza e a segunda, analógica com dou, estou, totalmente esporádica na língua atual, só se detetando nalguns pontos do galego das Astúrias (cfr. Fernández Rei 2003: 100). Daí que as amostras que se registam no cancioneiro, antes que procedentes de cantares dessas áreas do galego da faixa oriental, nos pareçam, de novo, provenientes de textos originariamente em português, que possui na sua variedade padrão a forma sou: agora que sou casada / traio os meus fillos nos brazos (CTE, $\mathrm{V})$; has de ser o derradeiro, / xúrote á fe de quen sou (CTE, I); etc.

\subsubsection{O uso dos tempos compostos}

Por último, para acabarmos com as principais questóes dos tempos verbais que observámos no $\mathrm{CTE}$, vamos tratar da documentação de tempos compostos. A conjugação do verbo galego na atualidade não conhece a existência destes complexos ao irem desaparecendo desde finais da Idade Média, pois habitualmente ambas as possibilidades, a simples e a composta, podiam funcionar como sinónimas ${ }^{21}$; de aí que, para o

20. Note-se que, de um ponto de vista diacrónico, Mariño Paz (2017: 68) indica a existência já medieval dos morfemas lexicais presentemente mais comuns: "Os lexemas dix-, fix-, pux- e quix-, maioritarios no galego contemporáneo para o tema de perfecto dos verbos irregulares dicir, facer, pórl poñer e querer, xa se coñecían na Idade Media, se ben (salvo en dix-) con probable consoante palatal sonora alí onde hoxe está xeneralizada a xorda. Estes lexemas con consoante palatal final alzáronse como alternativa fronte aos que tiñan consoante apicoalveolar (diss-, pus- ou pos-, quis- ou ques-) ou predorsodentoalveolar ( $f z$ - ou $f e z-$ )".

21. Repare-se no que comenta Moscoso Mato (2000: 185) quando faz referência a que "os tempos 
galego do nosso tempo, o aspeto verbal, em confronto com outras línguas, só tenha verdadeiro valor nos complexos verbais perifrásticos. A língua em Portugal, em confronto, ao manter a tradição literária e os usos normais em todas as esferas sociais, conseguiu consolidar os dois paradigmas e consagrou um modelo conjugacional em que os tempos compostos possuem verdadeiro valor funcional, a exprimirem conteúdos diferentes dos simples. Por isso, quando se deteta no galego contemporâneo certa sorte de formas compostas, construídas normalmente com o verbo ter como auxiliar e o particípio do verbo auxiliado, o mais recorrente é atribuir essa documentação à traduçáo de textos espanhóis ${ }^{22}$ ou à adaptação de textos portugueses. No cancioneiro tradicional galego não têm representatividade, no geral, exemplos de tais flexóes e, se aparecerem, surgem ambas estas hipóteses que acabam de ser expostas como as mais plausíveis causas. Por isso, ao se registarem no CTE, acudimos a elas, e nomeadamente à segunda explicação, para lhes procurarmos justificação, quando menos em aparentes casos como os seguintes: Teño mandado facer, / ou talvez xa estexa feito (CTE, II); Teño dito aos meus ollos / que vou darlles un castigo (CTE, II); xa tiña feito un castelo I no meio do mar salgado! (CTE, XIX); Fúcheste gabar, dixeche / que me tińas dado un beixo (CTE, I); tińa tido catro fillos / sin tratar de casamento (CTE, V); Dábache o meu corazón / si mo tiveras pedido (CTE, I); etc.

Porém, há exemplos no Cancioneiro em que a construção ter + particípio pode funcionar como um complexo verbal, em cujo caso, em vez de se interpretar como um tempo verbal, corresponde a uma perífrase aspetual com valor reiterativo-perfetivo, segundo consta nas gramáticas modernas (cfr. Freixeiro Mato 2006, II: 454-456) e conforme se aprecia nas estrofes a seguir: Teño andado moitas terras / aínda moitas andarei; / teño visto caras lindas, / como a túa non achei (CTE, II); Ti tes a monteira a un lado, I heicha de pór ó dereito, I que che quero perguntar / canto mal che teño feito (CTE, II); etc.

compostos conviven cos simples, expresando en ocasións formas simples e compostas os mesmos contidos temporais".

22. Contudo, nos inícios da tradição gramatical galega de finais do século XIX os tempos compostos foram considerados dentro dos paradigmas conjugacionais por certos autores. Com toda a segurança, o facto de compararen constantemente o galego com o espanhol, língua que lhes serve de referência permanente, é o que explica que tais formas figurem nessas obras, a refletirem uns tempos verbais alheios ao percurso evolutivo do galego. É o caso da gramática de Mirás (1864) ou de Marcial Valladares (1970), autores que não hesitam em recolher flexões do tipo *haiga ou * haxa feito, * había feito, etc. Nem mesmo foi possível a Saco Arce (1868: 175) ficar à margem desta influência do castelhano, pois, após indicar que "las principales diferencias entre el gallego y el castellano son debidas á la circunstancia de abundar menos el primero que el segundo en tiempos compuestos del verbo haber", não teve dúvidas em assinalar para o pretérito máis-que-perfeito do indicativo que dispunha de "tres formas, una simple terminada en ra y dos compuestas: puede decirse Xa acabára, ó tiña acabado, ó había acabado, cando ti chegaches [...]. La forma primera es la más usada; la tercera pocas veces se emplea”. 


\subsubsection{Os pronomes pessoais}

Entre as diferentes tipologias de pronomes no Cancioneiro que merecem umas palavras, as formas do pronome pessoal átono ou clíticos protagonizam particularidades dignas de nota. Em falares do Baixo Minho e nalguns pontos do ocidente da província de Leão o produto resultante da união do dativo de $\mathrm{P} 2$ com o acusativo é to, ta, tos, tas, dado que nessas regióes se emprega a forma te universalmente para dativo e para acusativo (cfr. ALGa, 1995: 174-175; Fernández Rei 2003: 76-77), como acontece no português. Entre os materiais coligidos por Torre Enciso aparecem esporadicamente vários exemplos desses conglomerados pronominais, que, a nosso ver, ou bem se devem a quadras compiladas nessas áreas ou bem se explicariam por uma transmissão ou compilação defetuosa ou bem seriam novamente mostras de adaptaçóes de cantares portugueses: Eu hei de te amar, amar / que to teño prometido (CTE, I); Tanta vez to teño dito: I rapaz, non seias larchán!; Non te quero, non te quero, I mesmo na cara to digo (CTE, II), etc.

Noutra ordem de ideias, um dos assuntos mais recorrentes da linguística galego- portuguesa é o que atinge a colocaçáo do clítico no interior da cláusula, para cuja descrição remetemos às modernas gramáticas de Álvarez e Xove (2002: 558-569), Freixeiro Mato (2006, II: 165-176) ou Raposo et al. (2013, II: 2231-2302). A disposiçáo dos pronomes átonos que se aprecia no CTE não difere no essencial da que hoje se conhece. Porém, é preciso salientarmos os numerosos exemplos de próclise do pronome átono a respeito de formas verbais infinitas, linearidade sentida hoje como mais literária e associada frequentemente a variedades linguísticas das faixas de idade mais altas. Eis alguns casos com infinitivos regidos por preposição: $A$ alegría de te ver I foi causa do meu penar (CTE, I); non hei de te deixar casar / nin hei de casar contigo (CTE, I); Antes de te coñecer / por ti nada se me daba (CTE, I); Coidabas, por me deixares I que eu cortaría o cabelo (CTE, I); Fun ó mar por me embarcar, I un pé dentro e outro fóra (CTE, I); E tras delas sempre andades / para lle facer as beiras (CTE, I); A troita anda no río / gozando de se bañar (CTE, I); co viño nunha bodega / para nos dar de beber (CTE, IX); E o probiño tremando está, I e non ten lume pra se quentar (CTE, IX); etc. Ainda que mais minoritários, há outros exemplos com gerúndios (Marica, teu pai querendo, I túa nai non cho privando, CTE, XV; tenche as que Dios lle dou I non lle faltando ningunha; CTE [pasta sem numerar]; etc.), os quais parecem tirados de outras coleçôes de literatura anónima ${ }^{23}$, conforme foi aflorado mais acima ( $\left.\$ 2.2 .1\right)$.

Mas, à margem destas disposiçóes do pronome átono, entre as estrofes compiladas por Torre Enciso aparecem outras colocaçóes que poderíamos qualificar de

23. Tal parece ser o caso da obra coligida por José Pérez Ballesteros, em que achamos as quadras que se seguem: Marica, teu pai querendo, I túa nai non ch'o privando, / eu seréi teu ceruxano / d'ese mal que estás pasando (CPG I, 167); -Nesta terr'e en toda terra, / anque sea en Cataluña, I tenche: "as que Dios lle dou / non lle faltando ningunha" (CPG II, 131). 
raras, nalguns casos, e forçadas, noutros, sobretudo se comparadas com as descriçóes na literatura especializada à volta do lugar dos clíticos na cláusula. A primeira dessas ordens singulares, documentada no Cancioneiro com uma relativa frequência, favorece a ênclise de formas verbais modo-temporais ou finitas quando introduzidas por uma conjunção, o que, deixando de lado algumas pontuais exceçóes contempladas nas gramáticas atuais ${ }^{24}$, não condiz no geral com as tendências da colocação dos pronomes átonos no âmbito galego-português europeu: aquele corpo ben feito / era o que pedinlle a Deus (CTE, I): Coidabas por me deixares / que cortariame o pelo (CTE, V); Eu hei d'ir a San Antonio / porque voume a regalar (CTE, XVII B); que quéimanme as charamuscas / miña cariña de rosas (CTE, V); etc. Possivelmente, o coletor interpretou como mais recomendável a ênclise, sendo sabedor, com muita probabilidade, de que a tendência geral no galego, quando menos nas cláusulas enunciativas afirmativas, corresponde a essa colocação, que é considerada não marcada.

O terceiro tipo de ordem sintática dos clíticos que chama a atençáo assenta numa certa documentação de determinadas próclises, habitualmente em complexos verbais, quando, em circunstâncias normais, a língua se foi decantando por outras possibilidades: dille que fico chorando / por non ir te acompañar (CTE, II) [gal. com. por non irte acompañar - por non ir acompañarte]; Non se me dá que te cases, I agora vou te perder (CTE, V) [gal. com. agora voute perder - agora vou perderte]; pra quedar descansadiño, I non quero te deber nada (CTE, VII) [gal. com. non che quero deber nada - non quero deberche nada]; Veña nos dar a xaneira / que fai un frío que mata (CTE, IX) [gal. com. Véñanos dar a xaneira - Veña darnos a xaneira]; vinde nos dar a xaneira / en louvanza de Santiago (CTE, IX) [gal. com. vindenos dar a xaneira vinde darnos a xaneira]; etc. Para a origem de tais disposiçóes - insólitas nos cancioneiros contemporâneos publicados -, parece-nos plausível acreditarmos na influência de certas obras gramaticais a que, talvez, Torre Enciso pôde ter aceso. Lembremos, em primeiro lugar, que se trata de uma colocaçáo do pronome recorrente no português brasileiro, conforme se assinala em trabalhos modernos (cfr., entre outros, Cunha / Cintra 1992: 317; Azeredo 2008: 261-262; etc.). E notemos, em segundo lugar, que algum estudioso galego, como Ricardo Carvalho Calero, lhe permitiu trespassar a alfândega do sintaticamente aceitável quando recolhe como colocaçóes possíveis "quero a ver, quero ve-la" e "quero-a ver" na sua Gramática (cfr. Carballo Calero 1979: 293). Outrossim, nalgumas destas amostras também poderia pensar-se numa simples e opcional questáo ortográfica (i.e. por non ir te acompañar, CTE, II; agora vou te perder, CTE, V; etc.), mas noutros casos tal explicação parece discutível por questóes gramaticais (i.e. non quero te deber nada, CTE, VII; etc.).

24. Algumas destas colocaçôes não podem ser explicadas por o nexo estar consideravelmente afastado do pronome ou por se perder a perceção da subordinação, conforme se dá noutros contextos em que tal hipótese explica essa ordem. Veja-se, neste sentido, Álvarez / Xove (2002: 564-565) ou Freixeiro Mato (2006, II: 167). 
Por outra parte, os verbos ditransitivos que exigem CD e CI (dar, dicir, pedir, etc.) podem levar um clítico de dativo a concordar com a FN que desempenhar aquela função sintática, o que é de regra quando esta for desenvolvida por uma forma oblíqua tónica do pronome persoal (i.e. Contoulle unha historia / Contoulle a ela unha historia / ${ }^{*}$ Contou a ela unha historia). Mas quando essa FN estiver representada por um substantivo e os seus adjacentes, o galego contemporâneo conhece duas possibilidades de construção: a primeira, hoje em dia a menos comum, consiste em não utilizar essa marca clítica, pois a própria $\mathrm{FN}$ já se ocupa da pertinente função de $\mathrm{CI}$; a segunda, presentemente muito mais habitual, enforma a cláusula tanto com essa $\mathrm{FN}$ em função de $\mathrm{CI}$ quanto com um pronome átono que marca a concordância entre o verbo e o tipo de complementação que exige, constituindo o que se conhece como "estruturas com redobro de clítico" (cfr. Duarte / Matos 1984; García-Miguel 1991; Cidrás Escáneo 1992). No Cancioneiro estão muito bem representadas ambas estas possibilidades: Á noite, cando me deito, / rezo á Virxen María (CTE, I); agora, só pido a Deus / que nin de día te atope (CTE, I); dá patacas ao seu home / e a carne cómea ela (CTE, IX); dai a vista ós meus ollos / que vos non costa diñeiro (CTE, XVII B); Meu amor, disme a quen diches / o meu anel de contiñas? (CTE, XV); que as teño moi gardadas / para dar ás costureiras (CTE, IX); etc. A túa nai xa llo dixen, / a teu pai téńolle medo (CTE, I); Agora xa non se estila / pedirlle a filla a seu pai (CTE, V); pidironlle a Sant'Antonio / que lles dese casamento (CTE, V); que picapica ás rapazas / e bótalle a culpa ós mozos (CTE, I); que ó meu amor un suspiro / no biquiño lle levara (CTE, I); sentado coél no talmo / pedinlle a filla ó patrón (CTE, II); vai e dille a aquela nena / que de sempre a quixen ben (CTE, II); etc.

A explicação para as duas hipóteses deve pôr-se em relação com diversos fatores. Por um lado, a mudança da ordem de elementos clausais mais normal (SVO) para outra menos habitual parece poder relacionar-se com um maior predomínio das estruturas com reforço do clítico, mais necessitadas de identificarem com clareza os papéis sintáticos dos constituintes da cláusula. Por outro lado, a consecuçáo de uma maior ênfase torna-se mais bem-sucedida com as construçóes com reforço do pronome átono do que com aquelas que não têm esta particularidade. E, igualmente, há quem aponte para uma possível influência do espanhol nas construçôes com reforço aludindo a que no português padrão moderno são residuais ${ }^{25}$. Como quer que seja, voltando à Galiza, as construções com redobro possuem uma extensíssima documentação, a teor dos dados que pudemos tirar relativos à sua grande presença na oralidade atual: de um total de 207 exemplos provenientes do Arquivo do Galego Oral (AGO), apenas 10 amostras correspondem a estruturas sem redobro e 197 a construçóes com essa duplicação (isto é, percentualmente, 4,83\% face a 95,16\%).

25. Não se tem de obviar, no entanto, que em variedades dialetais e populares de português ainda se podem atestar na atualidade e que houve algum autor, como Francisco José Freire, que defendia as tais estruturas no século XviII ao considerará-las "graças da indole da nossa lingua" (Freire 1842, parte $3^{\mathrm{a}}$ : 123) 


\subsection{Algumas questôes lexicais}

O vocabulário que aparece no cancioneiro tradicional galego-português está ligado de maneira muito especial aos modos de vida das comunidades rurais da Galiza e de Portugal. Campos semânticos e lexicais vinculados precisamente à vida quotidiana da gente camponesa e marinheira são os que caraterizam, portanto, o léxico das quadras populares de um ponto de vista diafásico, diastrático e diatópico: dança e instrumentos tradicionais, flora e fauna, gentílicos locais, indumentária, utensílios domésticos, etc. enformam um rico universo vocabular que, a não ser exclusivo deste tipo de manifestaçáo literária, sim que se torna num dos seus traços linguísticos mais importantes. $\mathrm{Na}$ atualidade, com o maior peso da vida citadina, uma notável parte desse vocabulário acha-se em desuso ou nos limites da obsolescência: pensemos, por exemplo, nas partes do carro tradicional camponês (cheda, chumaceiro, fungueiro, etc.), ou nas diferentes prendas da vestimenta denominada tradicional, tanto feminina quanto masculina (faldriqueira, lelha, mantelo, refaixo, etc.; cirolas, monteira, polainas, etc.), hoje praticamente só conhecidas por entidades etnográficas ou por ranchos folclóri$\cos ^{26}$. A este respeito, não se torna difícil concordarmos de alguma forma com a reflexão de Nunes (1975: XII) quando diz que o cancioneiro, neste caso o de José Leite de Vasconcellos, "é um documento do passado, mesmo quanto ao processo de recolha".

No caso galego, ao mesmo tempo, o vocabulário do cancioneiro pode servir como testemunha do uso de formas que se acham presentemente deslocadas pela influência do espanhol ou por outras galegas mais próximas do castelhano ou tendentes à confluência com esta língua. Os textos tradicionais presenteiam-nos às vezes com ilustrativos exemplos de léxico, como os dias da semana conforme a tradição cristã (domingo, segunda-feira, terça-feira, etc.), o verbo achar com o significado de 'encontrar', de licença com o valor de 'permissão', o substantivo lei com a equivalência de 'amor', 'respeito' ou 'consideração', a perífrase ter de + infinitivo, o verbo tirar com o significado tradicional de 'extrair', etc., e também o CTE oferece neste caso um comportamento similar: Hoxe é luns, mañán é martes, / cuarta feira logo vén (CTE, I); Quinta feira fai un ano / que contigo me casei (CTE, V); que eu canto con alegría / de non achar quen me queira (CTE, VI); quérote por moreniña / e pola lei que me tes (CTE, I); Vou cantar unha cantiga, I con licenza do meu pai (CTE, VI); etc. De madei-

26. Como dado para acrescentar aqui, temos de citar que entre as pessoas homenageadas no Dia das Letras Galegas por decisão da Real Academia Galega, Xoaquín Lorenzo Fernández (1907-1989) e Antón Fraguas Fraguas (1905-1999), foram dois autores que consagraram uma parte das suas vidas ao estudo da etnografia. E, relativamente a determinados campos lexicais que aparecem nas poesias dos cancioneiros, como os citados do carro camponês e da vestimenta, também devemos pôr em destaque que ambos estes investigadores se constituíram em verdadeiras referências no estudo dessas duas esferas etnográfico-linguísticas: lembre-se o filme-documentário "O carro e o home", rodado em 1940 sob a direção de Antonio Román e com o roteiro deste mesmo e de Xoaquín Lorenzo, ou o estudo da roupa tradicional galega levado a cabo por Fraguas Fraguas (1985). 
ra de cacique / teño de faguer un carro (CTE, V); mira que tes de pasar / unha ponte moi estreita (CTE, X); o que me queira amolar / ten de saír amolado (CTE, VII); Inda que o meu pai me bata, I miña nai me tire a vida (CTE, IX); etc.

Mas, junto a estes traços lexicais, comuns em diferentes coleçôes, há um outro tipo de caraterísticas vocabulares do Cancioneiro de Torre Enciso que se não atesta noutras obras de similar natureza, como é a presença de elementos lexicais portugueses, a evidenciar assim a origem ultra-minhota dos textos em que figuram. É certo que já desde finais do século XIX a variedade padrão de Portugal foi percebida como uma poderosa ferramenta para o galego recuperar no âmbito da literatura culta ${ }^{27}$ fenómenos gramaticais e vocábulos esquecidos ou lateralizados pela influência do espanhol (cfr. Freixeiro Mato / Sánchez Rei / Sanmartín Rei 2005: 682-689), alguns dos quais fazem hoje em dia parte da variedade padronizada (estudar e estudo, reitor, vogal, etc.) ou foram recorrentemente empregues no galego literário do século xx. Entre o vocabulário de fácil adscrição lusitana que delata essa origem e que só muito dificilmente poderia ser documentável na oralidade popular na Galiza, podemos expor as seguintes mostras: As asas dos paxariños / foron feitas pra voar (CTE, I); Quen namora a un estudante / fai dous pecados mortaes: / róuballe o tempo ao estudo (CTE, II); Vai polo ceo unha nuben, / todos contan "Ben a vin" (CTE, II); Fernandiño foi por viño, I quebrou o copo polo camiño (CTE, III); é bonito, gosto de ele I non me agrada máis ninguén (CTE, I); Menina, non te namores / de ouro nin fermosura (CTE, XIII); polo teu amor, meniña, / toda a vida andarei doudo (CTE, II); Lindos ollos son os teus, I ollos da miña doudice (CTE, XV); bota as raíces ó fundo; / eu non falo de ninguén, I de min fala todo o mundo! (CTE, XVII); Adeus, que me vou embora / para a semana que vén (CTE, XIX); etc.

No entanto, finalmente outros vocábulos, a serem comuns na Galiza e em Portugal, só conseguiram manter-se nos territórios do sul, enquanto nos setentrionais quase se consuma o seu desaparecimento, em certa congruência com o exposto com anterioridade $(\$ 3.2)$. Estamos a referir-nos a palavras como adeus, deus, desgraza e desgrazadalo, dubidar, pobo, só 'soa'28, etc., praticamente desconhecidas nos cantares galegos, mas habituais nos portugueses: no cancioneiro de José Pérez Ballesteros, por exemplo, a forma Deus atesta-se numa única ocasião a rimar com o pronome possessivo seus, o que é capaz de explicar a sua manutenção, já que na mesma quadra aparece * Dios (cfr. Dádelle limosna ô cego, I dade por amor de deus; / Dios vos poña os vosos

27. Veja-se Freixeiro Mato (2013: 212), que recolhe a recorrência ao português na literatura culta nos termos seguintes: "Outra dimensión estilística diferente [...] deben ter -e achamos que teñen- os portuguesismos (ou lusismos) pola identificación histórica entre galego e portugués e por este constituír para moitos autores e autoras un modelo máis ou menos ideal de galego escrito e literario".

28. Note-se que a crase -oa ['oa] > -ó ['o], de acordo com Fernández Rei (2003: 51), é residual territorialmente no galego, só se detetando nas duas margens da Ria de Arousa em palavras como avó (gal. com. avoa), filló (gal. com. filloa), mó (gal. com. moa), etc. 
ollos / como o cego tèn-os seus, CPG III, 194). Por isso, quando se regista esta forma e ainda outros vocábulos no CTE, surge a poderosa dúvida de se as tais palavras não seriam na verdade recuperadas desde a variedade lusitana ou de se as estrofes não procederiam diretamente do cancioneiro português. Eis alguns exemplos: Adeus montes, adeus vales, / adeus ríos que eu pasei (CTE, XIX); é como a ialma do corpo / cando Deus a quer levar (CTE, II); Eu hei de subir ó Ceo / a pedir a Deus por ti (CTE, V); $A$ miseria e a desgraza / non se desprezan, amor (CTE, VI); Xa coñecin a ventura, I agora son desgrazada (CTE, XVII); todos pasan, ningún cai, / só eu fun o desgrazado! (CTE, I); A frol da malva é vermella, / quen o ha de dubidar (CTE, I); Nunca tiveches motivos I para de min dubidar (CTE, XV); eu non falo de ninguén, I de min fala o pobo todo (CTE, X); Eu rubin ó limoeiro, / cortei unha só vergasta (CTE, I); etc.

\section{Conclusões}

Cipriano Torre Enciso (1902-1995), polígrafo e intelectual corunhês, faz parte da nómina de eruditos que se ocupou de colecionar textos de extração anónima, chegando a constituir materiais cuja cifra anda à volta dos 7.000 textos. Sabemos, mercê às conversas com a sua família, que se valeu para esse trabalho dos cantares que recolhia diretamente do povo nas suas viagens à Galiza e a Portugal. Também pudemos deduzir, depois de lido e contrastado o seu Cancioneiro com diferentes compilaçôes, que acudiu a outras coleçôes de literatura tradicional, a obras sobranceiras de autoria individual, como Cantares Gallegos de Rosalía de Castro, e a cancioneiros portugueses. É por isso que o valor dos materiais que coligiu é, no seu conjunto, variado - pois entram aqui diversos fatores -, ainda que muito digno de se ponderar globalmente.

Para além disto, há outras caraterísticas que contribuem eficazmente para singularizar o Cancioneiro de Cipriano Torre Enciso. De todas elas, quiçá a mais surpreendente seja o facto de o compilador adaptar textos portugueses para o galego, com as consabidas repercussóes sócio-culturais e gramaticais. Tal decisáo do coletor serve como elo de união com o sentir maioritário dos eruditos galegos e lusitanos que se ocuparam destas temáticas, segundo o qual existe uma evidente identidade cultural e linguística entre os cantares galaicos e os portugueses. No tocante a aspetos gramaticais e lexicais, a opção de Torre Enciso implicou o aparecimento de vocabulário e de estruturas morfossintáticas mais comuns no português que no galego ou, quando menos, normais em Portugal, mais escassa ou nulamente representadas no modelo de linguagem popular e coloquial do cancioneiro galego contemporâneo.

Em síntese, os materiais que fazem parte do cancioneiro de Cipriano Torre Enciso constituem uma muito representativa amostra da literatura tradicional galega e marcam um ponto de inflexão relativamente a outras obras similares ao incorporar 
o coletor, propositadamente, textos lusitanos, dando forma assim a um verdadeiro Cancioneiro Galego-Português.

\section{Agradecimentos}

$\mathrm{O}$ autor deste contributo quer agradecer às pessoas que se ocuparam das primeiras versóes do texto (colegas e revisores anónimos) as suas atenciosas leituras e as valiosas observaçóes sobre ele formuladas, as quais, sem dúvida, aprimoraram a qualidade inicial do trabalho; os erros ou inexatidóes que ainda persistirem são, naturalmente, da única responsabilidade do autor. Também quer expressar a sua gratidáo à Profa. Doutora Catalina T. Castillón (Lamar University, USA) pela sua generosidade e ajuda desinteressada no tratamento dos materiais inéditos do Cancioneiro de Torre Enciso. 


\section{Referências bibliográficas}

Afonso, Belarmino. 2005. Introito e prefácio à edição de 1985. Em José Chrys Chrystello (ed.), Cancioneiro transmontano. 13-18. Bragança: Santa Casa de Misericórdia de Bragança.

AGO = Fernández Rei, Francisco (dir.). 2010-. Arquivo do galego oral. Santiago de Compostela: Instituto da Lingua Galega. http://ilg.usc.es/ago/ (25/05/2019).

ALGa = ILG [Instituto da Lingua Galega]. 1990, 1995. Atlas lingüistico galego. Vol. I. Morfoloxía verbal. Vol. II. Morfoloxía non verbal. A Coruña: Fundación Pedro Barrié de la Maza.

Álvarez, Rosario \& Xosé Xove. 2002. Gramática da lingua galega. Vigo: Galaxia.

AT = Mato Fondo, Miguel Anxo \& María Pilar García Negro (eds.). 1990. Manuel Hortas Vilanova [pseudónimo de Manuel María], Andando a terra (1977-1987). Escolma. Vigo: A Nosa Terra.

Azeredo, José Carlos de. 2008. Gramática Houaiss da língua portuguesa. São Paulo: Fundação Antônio Houaiss / Publifolha.

Blanco [Pérez], Domingo (ed.). 1992. Introducción histórica. O papel das clases letradas na valoración e transmisión da literatura popular de Galicia entre 1745 e 1880. Em Domingo Blanco (ed.), $A$ poesía popular en Galicia. Recompilación, estudio e edición critica, 2 vols. Vol. I, 15-108. Vigo: Xerais.

Blanco Pérez, Domingo. 1994. Historia da literatura popular galega. Santiago de Compostela: Universidade.

Blanco [Pérez], Domingo. 1996. A literatura popular. Em Alberte Ansede Estraviz \& Cesáreo Sánchez Iglesias (dirs.), Historia da literatura galega. Vol. I, 225-256. Vigo: A Nosa Terra.

Blanco [Pérez], Domingo. 1997. Literatura popular de tradición oral. Em Xosé Manuel González Reboredo (coord.), Galicia. Vol. XXVIII, 254-285. A Coruña: Hércules de Ediciones.

BT = Machado y Álvarez, Antonio (dir.). 2009. Biblioteca de las tradiciones populares españolas. Tomo IV. Folk-Lore gallego. Miscelánea por Emilia Pardo Bazán y varios escritores de Galicia. De los maleficios y los demonios. Costumbres populares andaluzas. Sevilla: Extramuros. (Primeira edición 1884).

CA = Cotarelo Valledor, Armando (ed.). 1984. Cancioneiro da Agulla. Vigo: Galaxia.

Cabanillas, Ramón. 1976. [Introdución]. Em Ramón Cabanillas (ed.), Cancioneiro popular galego. 9-80. Vigo: Galaxia. (Primeira ediçao 1951).

Calo Lourido, Francisco, Francisco Carballo Carballo \& Anselmo López Carreira. 1997. Historia xeral de Galicia. Vigo: A Nosa Terra.

Carballo Calero, Ricardo. 1979. Gramática elemental del gallego común. Vigo: Galaxia. (Primeira edición 1966).

Carballo Calero, Ricardo. 1980. Novos testemunhos gráficos do galego decer 'dizer'. Verba 7, 203-207.

Castro, Ivo. 1991. Curso de história da lingua portuguesa. Lisboa: Universidade Aberta.

Cidrás Escáneo, Francisco Antonio. 1992. Sobre a función da concordancia. Consideracións a propósito das concordancias verbais anómalas. Verba 19, 41-53.

CMG = Sampedro Folgar, Casto (ed.). 2007. Cancionero musical de Galicia. . Colección de la Sociedad Arqueológica de Pontevedra. Reconstitución, introducción y notas bibliográficas por José Filgueira Valverde. Estudios críticos de Luís Costa, Xavier Groba, José Carlos Valle y Carlos Villanueva. Corunha / Pontevedra: Fundación Pedro Barrié de la Maza / Museo de Pontevedra. (Primeira ediçao 1942). 
$\mathrm{CO}=$ Blanco [Pérez], Domingo (ed.). 2001. José Casal Lois, Colección de cantares gallegos. Santiago de Compostela: Consello da Cultura Galega.

CPG = Pérez Ballesteros, José (ed.). 1979. Cancionero popular gallego y en particular de la provincia de la Coruña. Con un prólogo del ilustre mitógrafo portugués Theóphilo Braga, 3 vols. Madrid: Akal. (Primeira ediçao 1885-1886).

CPGA = Cabanillas, Ramón. 1976. Cancioneiro popular galego. Vigo: Galaxia. (Primeira edición 1951).

CPGAL = Schubarth, Dorothé \& Antón Santamarina (eds.). 1984-1995. Cancioneiro popular galego, 7 vols. A Coruña: Fundación Pedro Barrié de la Maza. http://cancioneiro.fundacionbarrie.org/

CPL = Lorenzo Fernández, Xoaquín (ed.). 1973. Cantigueiro popular da Limia Baixa. Vigo: Fundación Penzol / Galaxia.

CPP $=$ Nunes, Maria Arminda Zaluar (coord.). 1975-1983. José Leite de Vasconcellos, Cancioneiro popular português, 3 vols. Coimbra: Universidade.

$\mathrm{CPT}=$ Felgueiras, Guilherme (ed.). 1966. Cancioneiro popular transmontano e alto-duriense. Lisboa: Edição da Revista Ocidente.

$\mathrm{CTE}=$ Materiais inéditos que enformam o Cancioneiro compilado por Cipriano Torre Enciso.

Cunha, Celso \& Luís Filipe Lindley Cintra. 1992. Nova gramática do português contemporâneo. Lisboa: Sá da Costa. (Primeira ediçao 1984).

Díaz Carro, Pablo \& Olga Kirk Martínez. 2012. Cancioneiro de Cabana de Bergantiños. Corunha: Deputación Provincial.

Duarte, Inês Silva \& Gabriela Ardisson Matos. 1984. Clíticos e sujeito nulo no português: contribuiçôes para uma teoria de 'pro'. Boletim de Filologia 29, 479-538.

EC = Rielo Carballo, Nicanor (ed.). 1976. Escolma de Carballedo (Lugo). Vigo: Castrelos.

Fernández Rei, Francisco. 2003. Dialectoloxía da lingua galega. Vigo: Xerais. (Primeira ediçao 1990).

Fernández Salgado, Benigno \& Henrique Monteagudo Romero. 1995. Do galego literario ó galego común. O proceso de estandardización na época contemporánea. Em Henrique Monteagudo Romero (ed.), Estudios de Sociolingüistica galega. Sobre a norma do galego culto. 99-176. Vigo: Galaxia.

Ferreiro, Manuel. 1997. Gramática histórica galega. Vol. II. Lexicoloxía. Santiago de Compostela: Laiovento.

Ferreiro, Manuel. 1999. Gramática histórica galega. Vol. I. Fonética e morfosintaxe. Santiago de Compostela: Laiovento. (Primeira ediçao 1995).

Fraguas Fraguas, Antonio. 1985. El traje gallego. Corunha: Fundación Pedro Barrié de la Maza.

Freire, Francisco José. 1842. Reflexóes sobre a lingua portugueza. Lisboa: Sociedade Propagadora dos Conhecimentos Uteis. (Obra redigida no século XviII).

Freixeiro Mato, Xosé Ramón, Xosé Manuel Sánchez Rei \& Goretti Sanmartín Rei. 2005. A lingua literaria galega no século XIX. A Coruña: Universidade.

Freixeiro Mato, Xosé Ramón. 2006. Gramática da lingua galega, 4 vols. Vigo: A Nosa Terra. (Primeira ediçao 1998-2001).

Freixeiro Mato, Xosé Ramón. 2013. Estilistica da lingua galega. Vigo: Xerais. 
Freixeiro Mato, Xosé Ramón. 2017. Sobre historiografía gramatical e codificación lingüistica (19551971). O Epítome de gramática galega e outros textos. Monografía 12 da Revista Galega de Filoloxía. A Coruña: Universidade.

Frenk, Margit. 2006. Poesía popular hispánica: 44 estudios. México: Fondo de Cultura Económica.

García-Miguel, José M. 1991. La duplicación de complemento directo e indirecto como concordancia. Verba 18, 375-410.

Lima, Fernando de Castro Pires de. 1932. Afinidades galaico-minhotas do cancioneiro popular. Arquivos do Seminario de Estudos Galegos 6, 239-256.

Lorenzo Fernández, Xoaquín. 1973. [Introdución]. Em Xoaquín Lorenzo Fernández (ed.), Cantigueiro popular da Limia Baixa. 7-25. Vigo: Fundación Penzol / Galaxia.

LPG = Saco Cid, José Luís (ed.). 1987. Literatura popular de Galicia. Colección de coplas, villancicos, diálogos, romances, cuentos y refranes gallegos. Recogidos por D. Juan Antonio Saco Arce. Ourense: Deputación Provincial.

Mariño Paz, Ramón. 2003. O idioma galego no limiar da súa renacenza. Monografía 2 da Revista Galega de Filoloxía. A Coruña: Universidade.

Mariño Paz, Ramón. 2017. Fonética e fonoloxía históricas galegas. Vigo: Xerais.

Martins, Nilce Sant’Anna. 2000. Introdução à estilística. A expressividade na língua portuguesa. São Paulo: T. A. Queiroz / Universidade. (Primeira ediçao 1989).

Mirás, Francisco. 1864. Compendio de gramática gallega-castellana, con un vocabulario de nombres y verbos gallegos y su correspondencia castellana, precedido de unos diálogos sobre diferentes temas. Un grandioso poema de 100 octavas titulado "La Creación y la Redención". Un extracto de fábulas de los mejores fabulistas así como algunas del autor. Santiago de Compostela: Establecimiento tipográfico de Manuel Mirás.

Monteagudo, Henrique. 2005. Do uso á norma. Da norma ao uso (Variación sociolingüística e estandarización do idioma galego). Em Rosario Álvarez \& Henrique Monteagudo (eds.), Norma linguística e variación. Unha perspectiva desde o idioma galego. 377-346. Santiago de Compostela: Consello da Cultura Galega / Instituto da Lingua Galega.

Moscoso Mato, Eduardo. 2000. Os tempos compostos no galego medieval. Anexo 46 de Verba. Santiago de Compostela: Universidade.

Nunes, Maria Arminda Zaluar. 1975. Introdução. Em Maria Arminda Zaluar Nunes (coord.) \& José Leite de Vasconcellos, Cancioneiro popular português. Vol. I, VII-XXXIX. Coimbra: Universidade.

PA = Torre Enciso, Cipriano. 1958. Panxoliñas. Retabro galego de Nadal. Madrid: Imprenta Acati. (Primeira ediçao 1956).

PGA = Blanco, Domingo (ed.). 1992. A poesía popular en Galicia. Recompilacion, estudio e edición critica, 2 vols. Vigo: Xerais.

PLM = Hermida, Carme (comp.). 2003. Polo mar abaixo vai... Cantigas populares sobre o mar. Santiago de Compostela: Edicións Positivas.

$\mathrm{RAG}=[$ Real Academia Gallega]. 1970. Normas ortográficas do idioma galego. A Coruña: Imprenta Moret.

RAG / ILG = [Real Academia Galega / Instituto da Lingua Galega]. 2003. Normas ortográficas e morfolóxicas do idioma galego. A Coruña: RAG / ILG. (Primeira ediçao 1982). 
Raposo, Eduardo Buzaglo Paiva, Maria Fernanda Bacelar do nascimento, Maria Antónia Coelho da Mota, Luísa Segura \& Amália Mendes. 2013. Gramática do português, 3 vols. Lisboa: Fundação Calouste Gulbenkian.

Rielo Carballo, Nicanor. 1976. Limiar. Em Nicanor Rielo Carballo (ed.), Escolma de Carballedo (Lugo). 11-40. Vigo: Castrelos.

Saavedra, Pegerto. 1992. A vida cotiá na Galicia de 1550 a 1850. Santiago de Compostela: Universidade.

Saco Arce, Juan Antonio. 1868. Gramática gallega. Lugo: Imprenta de Soto Freire.

Sánchez Rei, Xosé Manuel. 2006. A lingua galega no Cancioneiro de Pérez Ballesteros. Ames-Santiago de Compostela: Laiovento.

Sánchez Rei, Xosé Manuel. 2008. O português popular europeu dos séculos XVI-XIX e a sua importância para o estudo do Galego Médio. Revue Romane 43/2, 248-272. https://doi.org/10.1075/ rro.43.2.05rei

Sánchez Rei, Xosé Manuel. 2016. A información dialectal nos cancioneiros galegos oitocentistas: a importancia de Pérez Ballesteros e de Saco Arce. Em Alexandre Rodríguez Guerra (ed.), Lingüistica histórica e dialectoloxía: Coordenadas do cambio lingüistico. 239-272. Vigo: Universidade.

Sánchez Rei, Xosé Manuel \& Catalina T. Castillón. 2019. Traditional galician Cancioneiro compiled by Cipriano Torre Enciso. Vol. II. Edition. New York (USA) / Ceredigion (Wales): The Edwin Mellen Press.

Schubarth, Dorothé \& Antón Santamarina. 1982. Cancioneiro galego de tradición oral. A Coruña: Fundación Pedro Barrié de la Maza.

Valladares, Marcial. 1970. Elementos de gramática gallega. Vigo: Galaxia. (Redirigidos en 1892).

Vasconcellos, José Leite de. 1928. Opúsculos. Vol. II. Dialectologia (Parte I). Coimbra: Universidade.

Vasconcellos, José Leite de. 1985. Opúsculos. Vol. VI. Dialectologia (Parte II). Organizado por Maria Adelaide Valle Cintra. Notícia Introdutória de Orlando Ribeiro. Lisboa: Imprensa Nacional-Casa da Moeda. 


\section{Apêndice}

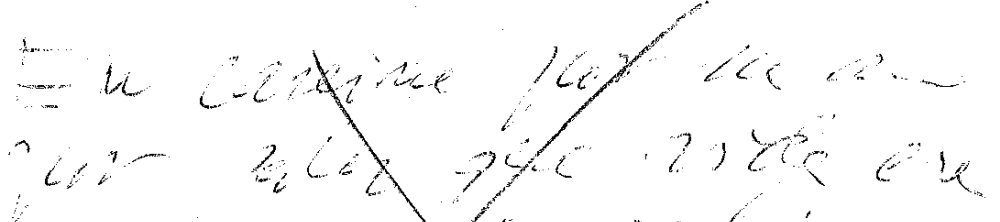

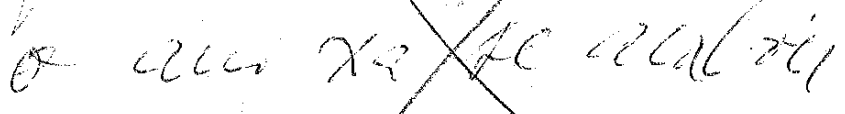

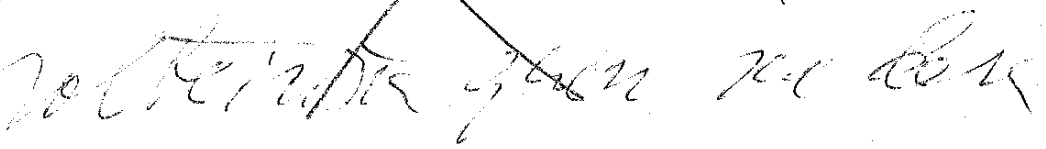

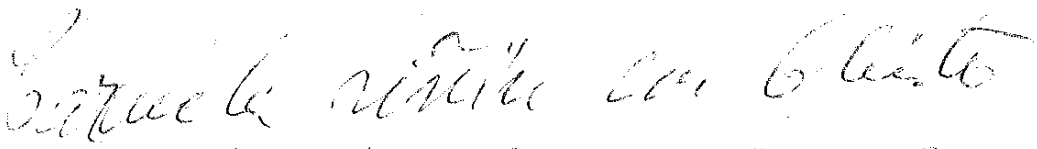

$$
\begin{aligned}
& \text { in } 4 \text { Q }
\end{aligned}
$$

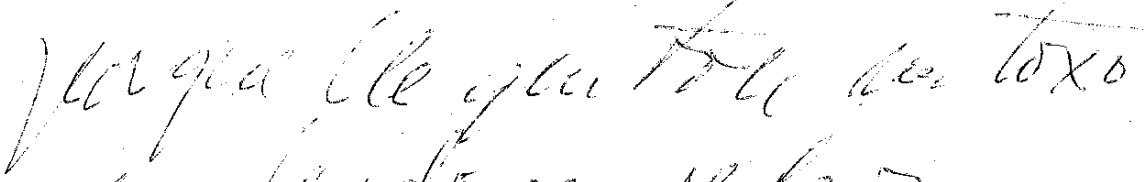

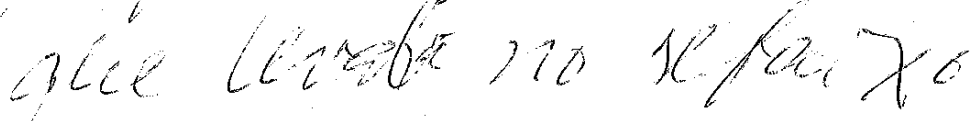

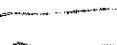

Versos manuscritos provenientes dos materiais do CTE. 